\title{
Antibacterial Effect of Ginger (Zingiber officinale) Roscoe and Bioactive Chemical Analysis using Gas Chromatography Mass Spectrum
}

\author{
HASANAIN KHALEEL SHAREEF ${ }^{1}$, HAIDAR J. MUHAMMED ${ }^{2}$, \\ HAIDER MASHKOOR HUSSEIN ${ }^{3}$ and IMAD HADI HAMEED ${ }^{4}$ \\ 'Department of Biology, Babylon University, Iraq. \\ ${ }^{2}$ College of Science, Almustansriya University, Iraq. \\ ${ }^{3}$ College of Science, Al-Qadisiya University, Iraq. \\ ${ }^{4}$ Department of medical science, Babylon University, Iraq. \\ *Corresponding E-mail: imad_dna@yahoo.com \\ http://dx.doi.org/10.13005/ojc/320207
}

(Received: February 06, 2016; Accepted: March 09, 2016)

\begin{abstract}
The objectives of this research was to determine the chemical composition of roscoe extract from methanol and evaluation of antibacterial activity. The phytochemical compound screened by GC-MS method. Forty eight bioactive phytochemical compounds were identified in the methanolic extract of Zingiber officinale. The identification of phytochemical compounds is based on the peak area, retention time molecular weight, molecular formula, MS Fragment-ions and pharmacological actions. GC-MS analysis of Zingiber officinale revealed the existence of the Octanal, 2-Naphthale namine, 1,2,4a,5,6,7,8,8a-octahydro-4a-methyl, 1-(Cyclopropyl-nitro-methyl)-cyclopentanol, EndoBorneol, Decanal, 1,2-15,16-Diepoxyhexadecane, Propanal,2-methyl-3-phenyl, Benzeneacetic acid ,4-(1H-1,2,3,4-tetrazol-1-yl), Ascaridole epoxide, 2-Methoxy-4-vinylphenol, 6-epi-shyobunol, Phenol,2-methoxy-5-(1-propenyl)-,E, Alfa.-Copaene, 8-Isopropenyl-1,5-dimethyl-cyclodeca-1,5diene, Bicyclo[3.1.0]hexane-6-methanol,2-hydroxy-1,4,4-trimethyl, 7-epi-cis-sesquisabinene hydrate, Alloaromadendrene, Benzene,1-(1,5-dimethyl-4-hexenyl)-4-methyl, 1,3-Cyclohexadiene ,5-(1,5-dimethyl-4-hexenyl)-2methyl-,[S- $\left.\left(\mathrm{R}^{*}, \mathrm{~S}^{*}\right)\right]$, Aromadendrene oxide, 1,6,10-Dodecatrien-3ol,3,7,11-trimethyl-,(E), 4-((1H)-3-Hydroxy-1-propenyl)-2-methoxyphenol, Butan-2-one,4-(3-hydroxy2-methoxyphenyl), Longipinocarveol,trans, Cholestan-3-ol,2-methylene-,(3ß,5á)-, Bicyclo[4.4.0] dec-2-ene-4-ol,2-methyl-9-(prop-1-en-3-ol-2-yl)-, Corymbolone, Estra-1,3,5(10)-trien-17ß-ol, 1-Heptatriacotanol, Fenretinide, Folic acid, Spiro[4.5]decan-7-one,1,8-dimethyl-8,9-epoxy-4isopropyl-, 7H-6,9a-Methano-4H-cyclopenta[9,10] cyclopropa[5,6]cyclodeca[1, Gingerol, 1b,4aEpoxy-2H-cyclopenta[3,4]cyclopropa [8,9]cycloundec[1,2-b]o, Cyclopropa[5,6]-A-nor-5á-androstane3,7-dione,3',6ß-dihydro-17ß-h, Olean-12-ene-3,15,16,21,22,28-hexol,(3ß,15á,16á,21ß,22á)-, Benz[e]azulen-3(3aH)-one,4,6a,7,8,9,10,10a,10b-octahydro-3a,8,1, Naphthalene, decahydro-1pentadecyl-, 13-Docosenamide,(Z)-, 9,10-Secocholesta-5,7,10(19)-triene-3,24,25-triol, (3ß,5Z,7E)-, $\mathrm{n}$-(2,4-Dinitrophenyl)- $\mathrm{N}^{\prime}-13-\left(2,6,6\right.$-trimethyl-cyclohex-1-enyl)propylider, $\mathrm{n}$-(2,4-Dinitrophenyl)- $\mathrm{N}^{\prime}$ 13-(2,6,6-trimethyl-cyclohex-1-enyl)propylider, Ingol 12-acetate, 2,2,4-Trimethyl-3-(3,8,12,16tetramethyl-heptadeca-3,7,11,15-tetrae, Piperine, 2-Methylcortisol, 9-Desoxo-9-x-acetoxy-3,8,12,-triO-acetylingol and Propanoic acid ,2-(3-acetoxy-4,4,14-trimethylandrost-8-en-17-yl. Methanolic extract of bioactive compounds of Zingiber officinale was assayed for in vitro antibacterial activity against
\end{abstract}


Proteus mirabilis, Escherichia coli, Pseudomonas aerogenosa, Proteus mirabilis, Staphylococcus aureus and Klebsiella pneumonia by using the diffusion method in agar. The zone of inhibition were compared with different standard antibiotics. The diameters of inhibition zones ranged from $4.93 \pm 0.290$ to $0.89 \pm 0.210 \mathrm{~mm}$ for all treatments.

Keywords: Antibacterial, GC/MS, Bioactive compounds, Zingiber officinale

\section{INTRODUCTION}

Ginger (Zingiber officinale Roscoe, fam. Zingiberaceae) is a perennial herb, slender perennial plant that reaches the height of two feet and has greenish yellow flowers resembling orchids. The rhizome is horizontal, branched, fleshy, aromatic, white or yellowish to brown. Leaves are narrowly or linear-lanceolate, up to $20 \mathrm{~cm}$ long and 1.5-2 $\mathrm{cm}$ wide. The dried rhizome of ginger contains approximately $1-4 \%$ of volatile oils which are the medicinally active constituents and are also responsible for the characteristic odour and taste. Flowers are produced in a dense spike, yellow green with purple endings. This plant is widely distributed in South-Eastern Asia ${ }^{1}$. It has a long history of medicinal use dating back 2500 years in China and India for conditions such as nausea and vomiting, diarrhea, dyspepsia, rheumatism, and colds $^{2}$. Other pharmacological actions of ginger and compounds isolated from it include anti-inflammatory, antioxidant ${ }^{3}$; hypoglycemic ${ }^{4}$; analgesic, antiplatelet ${ }^{5}$, antiemetic ${ }^{6,7}$, antithrombotic, anti-tumorigenic, radio protective, antimicrobial, antifungal actions ${ }^{8,9}$. The major pungent compounds in ginger include potentially active gingerols, which can be converted to shogaols, zingerone, and paradol. 6-gingerol appears to be responsible for characteristic taste of ginger and together with 6-shogaol have been shown to have antipyretic, analgesic, anti-inflammatory, anti-tussive and hypotenssive effects ${ }^{10,11}$. Patients with chronic and painful diseases often seek alternative therapy, and currently ginger is one of the most popular herbal medications for inflammatory diseases ${ }^{12}$. In food industry, both pathogenic and food spoilage bacteria can attach and form a biofilm on food contact surfaces and food product, on the other hand $Z$. officinale is widely used as spice, so the aim of this study was ginger effectiveness in preventing this problem through the evaluation of antibacterial activity of methanolic extract of $Z$. officinale.

\section{MATERIALS AND METHODS}

\section{Collection and preparation of plant material}

The roscoe were dried at room temperature for ten days and when properly dried then powdered using clean pestle and mortar, and the powdered plant was size reduced with a sieve. The fine powder was then packed in airtight container to avoid the effect of humidity and then stored at room temperature ${ }^{13,14}$.

\section{Preparation of sample}

About seven grams of the plant sample powdered were soaked in $80 \mathrm{ml}$ methanol individually. It was left for 72 hours so that alkaloids, flavonoids and other constituents if present will get dissolved. The methanol extract was filtered using Whatman No.1 filter paper and the residue was removed ${ }^{15,16}$.

\section{Gas chromatography - Mass Spectrum analysis}

The GC-MS analysis of the plant extract was made in a (789 Agilent) instrument under computer control at $70 \mathrm{eV}$. About $1 \mathrm{iL}$ of the methanol extract was injected into the GC-MS using a micro syringe and the scanning was done for 45 minutes ${ }^{17,18}$. As the compounds were separated, they eluted from the column and entered a detector which was capable of creating an electronic signal whenever a compound was detected. The greater the concentration in the sample, bigger was the signal obtained which was then processed by a computer. The time from when the injection was made (Initial time) to when elution occurred is referred to as the retention time (RT). While the instrument was run, the computer generated a graph from the signal called Chromatogram. Each of the peaks in the chromatogram represented the signal created when a compound eluted from the Gas chromatography column into the detector ${ }^{19,20}$. The $\mathrm{x}$-axis showed the RT and the $\mathrm{y}$-axis measured the intensity of the signal to quantify the component 
Table 1: Bioactive Chemical Compounds Identified In Methanolic Extract of Zingiber Officinale

\begin{tabular}{|c|c|c|c|c|c|c|c|c|}
\hline $\begin{array}{l}\text { S. } \\
\text { No. }\end{array}$ & $\begin{array}{l}\text { Phytochemical } \\
\text { compound }\end{array}$ & $\begin{array}{c}\mathrm{RT} \\
\text { (min) }\end{array}$ & Formula & $\begin{array}{l}\text { Molec. } \\
\text { Weight }\end{array}$ & $\begin{array}{l}\text { Exact } \\
\text { Mass }\end{array}$ & $\begin{array}{l}\text { Chemical } \\
\text { structure }\end{array}$ & $\begin{array}{l}\text { MS } \\
\text { Fragment- } \\
\text { ions }\end{array}$ & $\begin{array}{l}\text { Pharmacological } \\
\text { actions }\end{array}$ \\
\hline 1 & Octanal & 3.888 & $\mathrm{C}_{85} \mathrm{H}_{16} \mathrm{O}$ & 128 & 128.12 & & $\begin{array}{l}56,69 \\
84,100,128\end{array}$ & $\begin{array}{l}\text { Antioxidant } \\
\text { activity and anti } \\
\text {-inflammatory } \\
\text { activities }\end{array}$ \\
\hline 2 & $\begin{array}{l}\text { 2-Naphthalenamine, } \\
\text { 1,2,4a,5,6,7,8,8a- } \\
\text { octahydro-4a-methyl }\end{array}$ & 4.987 & & 165 & 165.152 & & $\begin{array}{l}55,67,81 \\
96,109,121 \\
135,150,165\end{array}$ & $\begin{array}{l}\text { Anti-inflammatory, } \\
\text { analgestic and } \\
\text { antimicrobial } \\
\text { properties }\end{array}$ \\
\hline 3 & $\begin{array}{l}\text { 1-(Cyclopropyl-nitro } \\
\text {-methyl)- } \\
\text { cyclopentanol }\end{array}$ & 5.702 & & 185 & 185.105 & & $\begin{array}{l}55,69,85 \\
95,121,139\end{array}$ & $\begin{array}{l}\text { Anti-muscarinic } \\
\text { properties. }\end{array}$ \\
\hline 4 & Endo-Borneol & 5.982 & $\mathrm{C}_{10} \mathrm{H}_{18} \mathrm{O}$ & 154 & 154.136 & & $\begin{array}{l}55,67,79,95 \\
110,121 \\
139,152\end{array}$ & $\begin{array}{l}\text { Antinociceptive } \\
\text { and anti- } \\
\text { inflammatory } \\
\text { activities }\end{array}$ \\
\hline 5 & Decanal & 6.417 & $\mathrm{C}_{10} \mathrm{H}_{20} \mathrm{O}$ & 156 & 156.151 & & $\begin{array}{l}57,70,82 \\
95,112,128 \\
138,155\end{array}$ & $\begin{array}{l}\text { Anti-Salmonella } \\
\text { agents and } \\
\text { antioxidant } \\
\text { activity }\end{array}$ \\
\hline 6 & $\begin{array}{l}\text { 1,2-15,16- } \\
\text { Diepoxyhexadecane }\end{array}$ & 6.697 & $\mathrm{C}_{16} \mathrm{H}_{30} \mathrm{O} 2$ & 254 & 254.225 & & $\begin{array}{l}55,71,81 \\
95,178 \\
211,254\end{array}$ & $\begin{array}{l}\text { Antitumor and } \\
\text { anti-inflammatory } \\
\text { agents }\end{array}$ \\
\hline 7 & $\begin{array}{l}\text { Propanal,2- } \\
\text { methyl-3-phenyl }\end{array}$ & 6.932 & $\mathrm{C}_{10} \mathrm{H}_{12} \mathrm{O}$ & 148 & 148.089 & & $\begin{array}{l}51,63,77 \\
91,105,119 \\
133,148\end{array}$ & $\begin{array}{l}\text { Various biological } \\
\text { activities such } \\
\text { as anti- } \\
\text { inflammatory }\end{array}$ \\
\hline 8 & $\begin{array}{l}\text { Benzeneacetic acid, } \\
\text { 4-(1H-1,2,3,4- } \\
\text { tetrazol-1-yl) }\end{array}$ & 7.338 & & 204 & 204.065 & & $\begin{array}{l}51,77,89 \\
104,131 \\
149,204\end{array}$ & Antimicrobial \\
\hline 9 & $\begin{array}{l}\text { Ascaridole } \\
\text { epoxide }\end{array}$ & 7.75 & $\mathrm{C}_{10} \mathrm{H}_{16} \mathrm{O}_{3}$ & 184 & 184.11 & & $\begin{array}{l}55,69,79, \\
91,97,107, \\
117,135, \\
150,168\end{array}$ & $\begin{array}{l}\text { Anti- } \\
\text { carcinogenic } \\
\text { effects }\end{array}$ \\
\hline 10 & $\begin{array}{l}\text { 2-Methoxy-4- } \\
\text { vinylphenol }\end{array}$ & 7.928 & $\mathrm{C}_{9} \mathrm{H}_{10} \mathrm{O}_{2}$ & 150 & 150.068 & & $\begin{array}{l}51,77,89 \\
107,121,135\end{array}$ & $\begin{array}{l}\text { Antioxidant, } \\
\text { anti microbial } \\
\text { and anti } \\
\text { inflammatory. }\end{array}$ \\
\hline 11 & 6-epi-shyobunol & 8.208 & $\mathrm{C}_{15} \mathrm{H}_{26} \mathrm{O}$ & 222 & 222.198 & & $\begin{array}{l}55,67,81,93, \\
109,121,136, \\
153,161, \\
189,207, \\
222\end{array}$ & $\begin{array}{l}\text { Anti-inflammatory, } \\
\text { antinociceptive } \\
\text { and antipyretic } \\
\text { effects }\end{array}$ \\
\hline
\end{tabular}




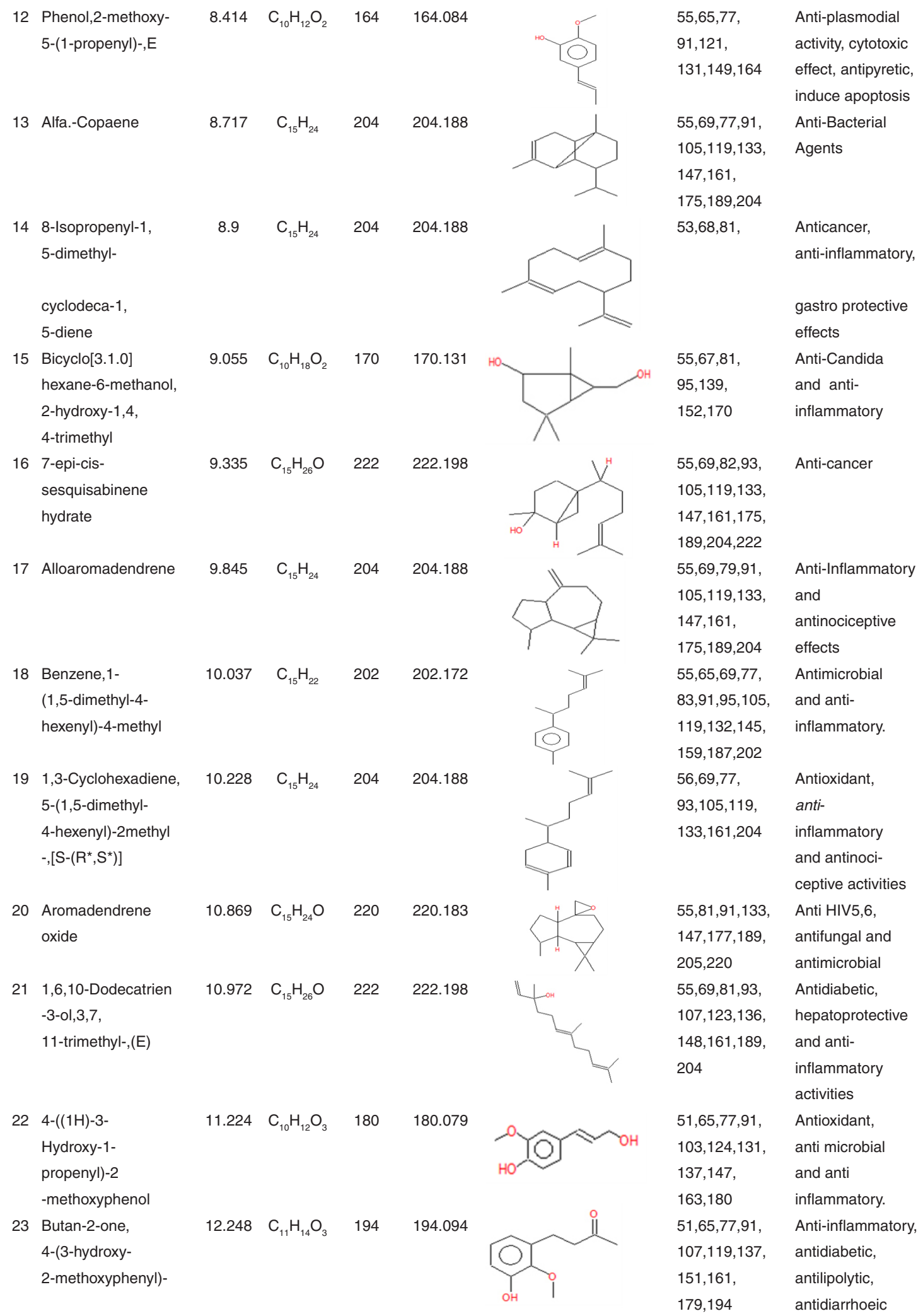




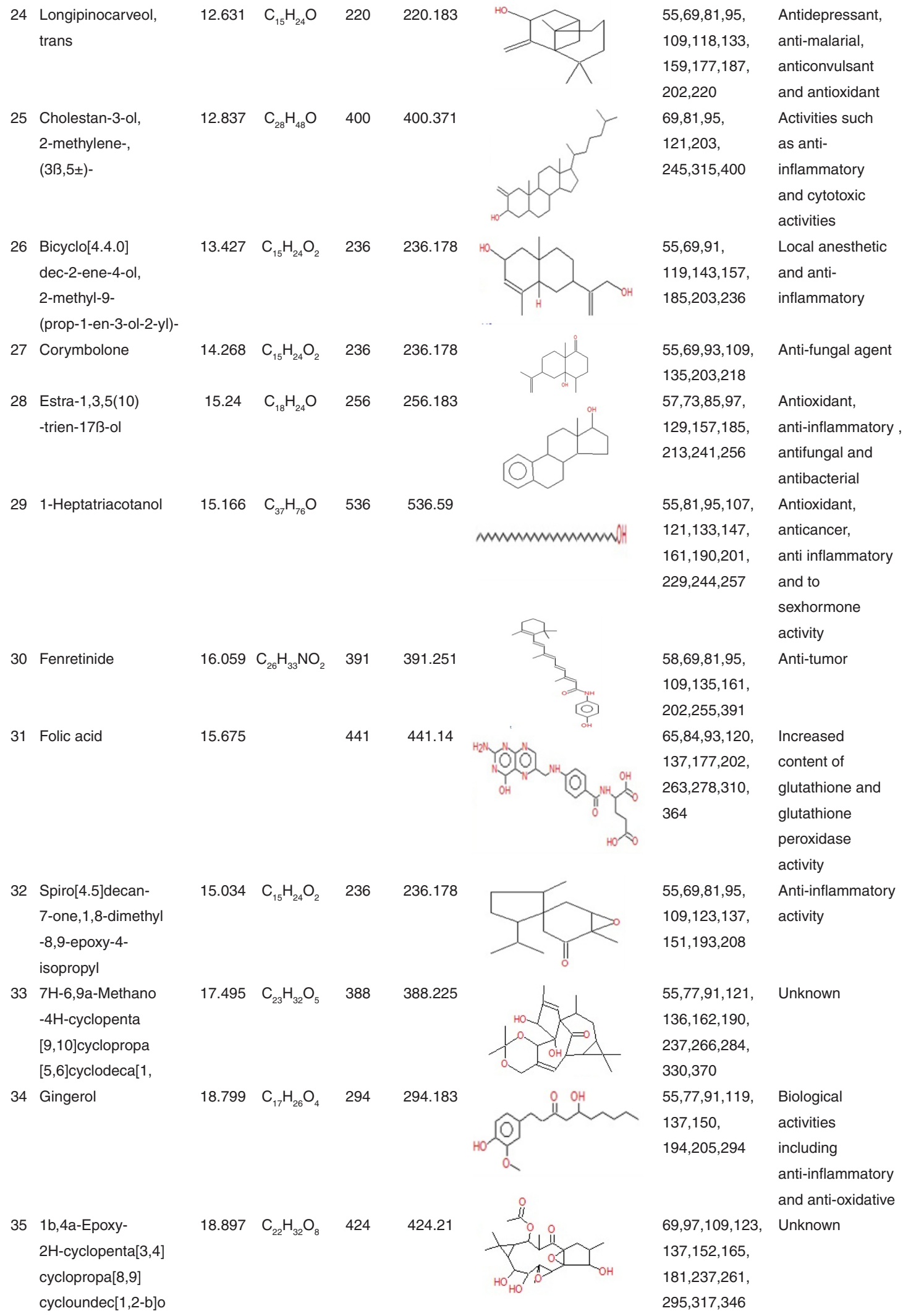




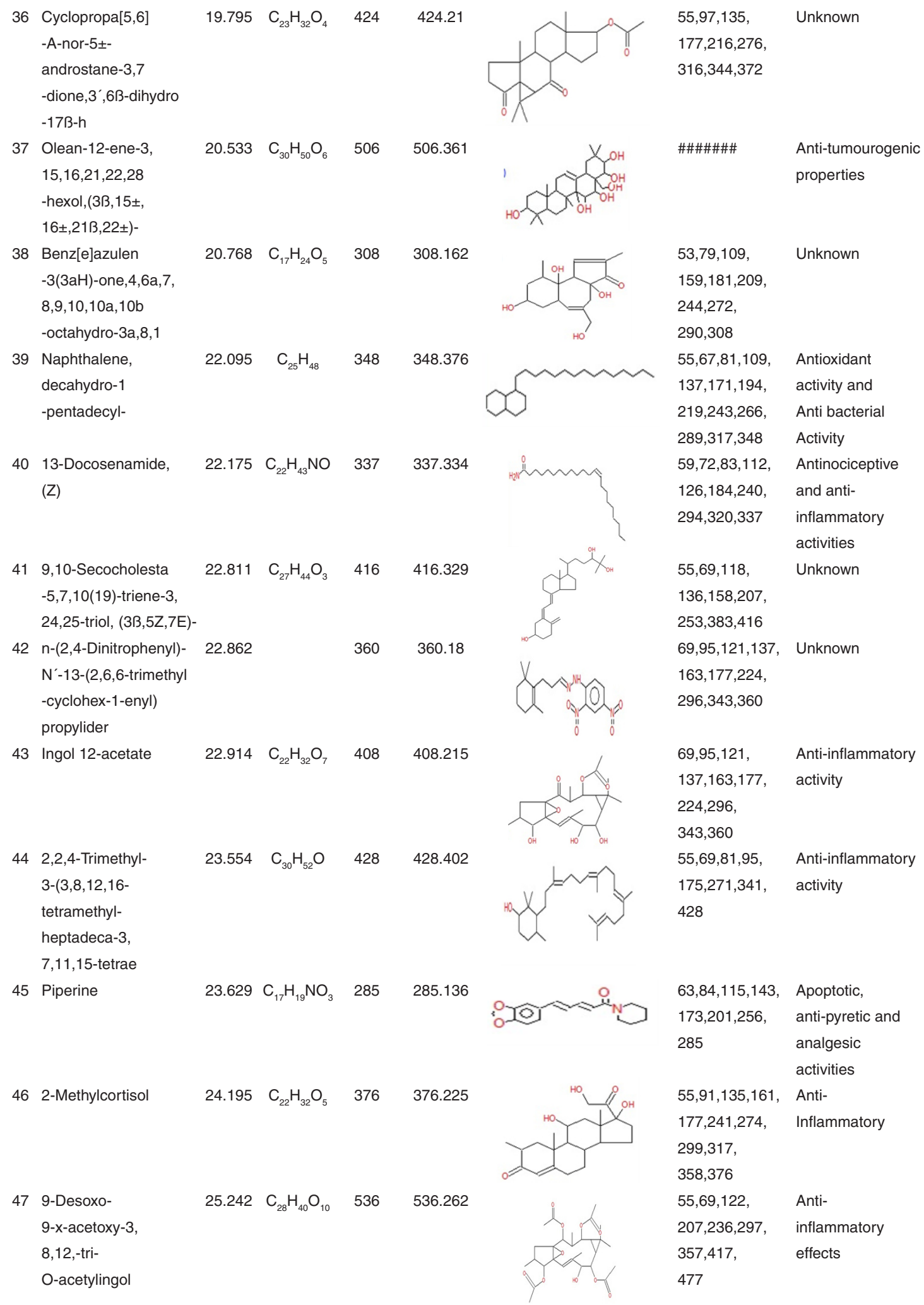




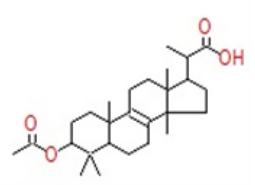

55,69,121,159, Antihyperglycem, 233,281,337, hypolipidemic 355,415 and antimicrobial.

Table 2: Zone Of Inhibition (Mm) Of Test Bacterial Strains To Zingiber Officinale Bioactive Compounds And Standard Antibiotics

\begin{tabular}{|c|c|c|c|c|}
\hline \multirow[t]{2}{*}{ Bacteria } & \multicolumn{4}{|c|}{ Plant (Zingiber officinale)/ Antibiotics } \\
\hline & Zingiber officinale & Streptomycin & Rifambin & Cefotoxime \\
\hline Pseudomonas eurogenosa & $4.01 \pm 0.188$ & $0.92 \pm 0.210$ & $1.04 \pm 0.300$ & $1.183 \pm 0.100$ \\
\hline Escherichia coli & $2.99 \pm 0.311$ & $1.500 \pm 0.141$ & $0.99 \pm 0.240$ & $2.20 \pm 0.170$ \\
\hline Klebsiella pneumonia & $4.93 \pm 0.290$ & $2.02 \pm 0.361$ & $1.05 \pm 0.161$ & $0.93 \pm 0.150$ \\
\hline Staphylococcus aureus & $3.75 \pm 0.910$ & $1.00 \pm 0.102$ & $2.00 \pm 0.140$ & $1.00 \pm 0.301$ \\
\hline Proteus mirabilis & $1.99 \pm 0.200$ & $2.00 \pm 0.180$ & $2.06 \pm 0.300$ & $0.89 \pm 0.210$ \\
\hline
\end{tabular}

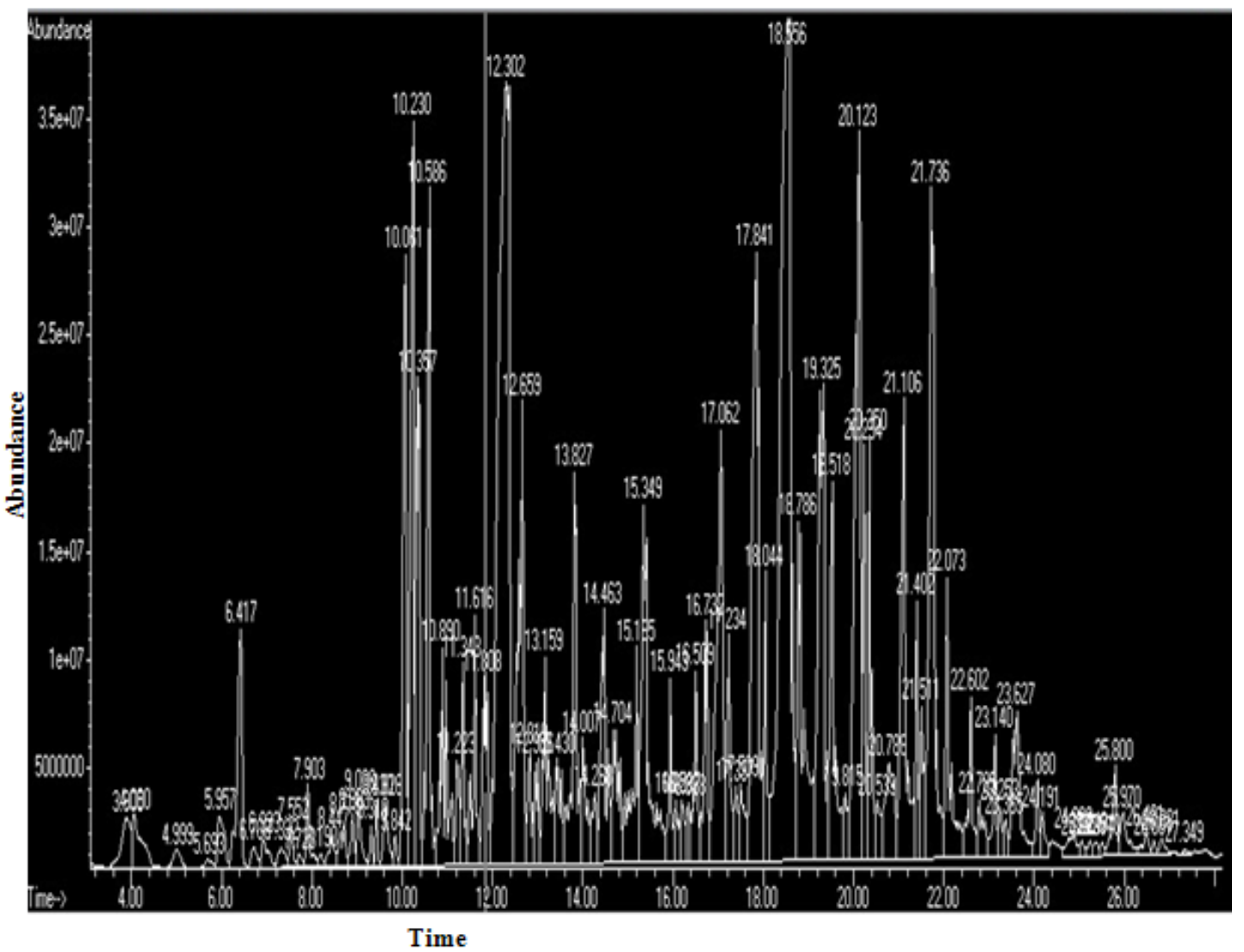

Fig. 1: GC-MS chromatogram of methanolic extract of Zingiber officinale 
in the sample injected. As individual compounds eluted from the gas chromatographic column, they entered the electron ionization (mass spectroscopy) detector, where they were bombarded with a stream of electrons causing them to break apart into fragments. The fragments obtained were actually

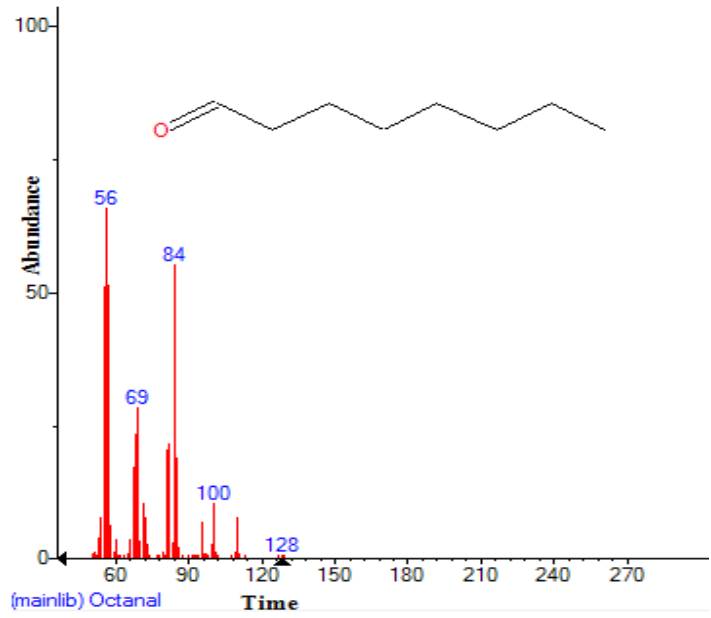

Fig. 2: Structure of Octanal present in Zingiber officinale with retention time $=3.888$ using GCMS analysis

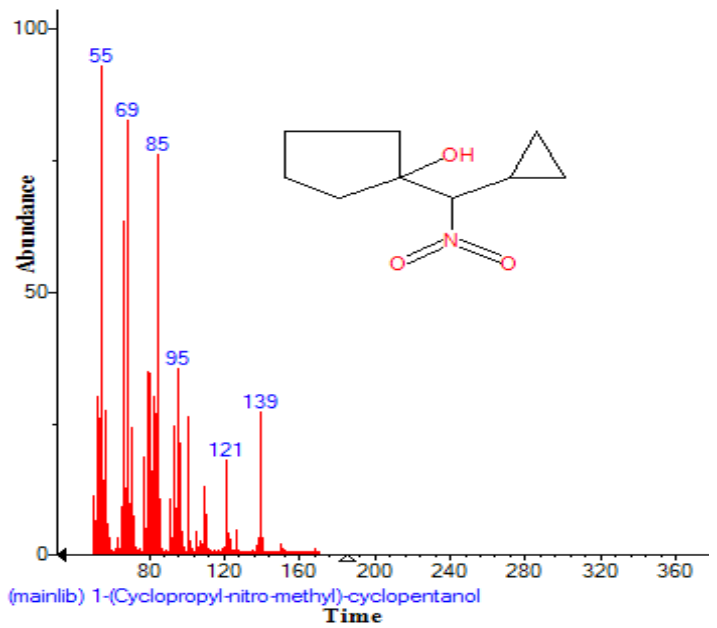

Fig. 4: Structure of 1-(Cyclopropyl-nitromethyl)-cyclopentanol present in Zingiber officinale with retention time $=5.702$ using GCMS analysis charged ions with a certain mass ${ }^{21}$. The $M / Z$ (mass / charge) ratio obtained was calibrated from the graph obtained, which was called as the Mass spectrum graph which is the fingerprint of a molecule. Before analyzing the extract using gas Chromatography and Mass Spectroscopy, the temperature of the oven, the

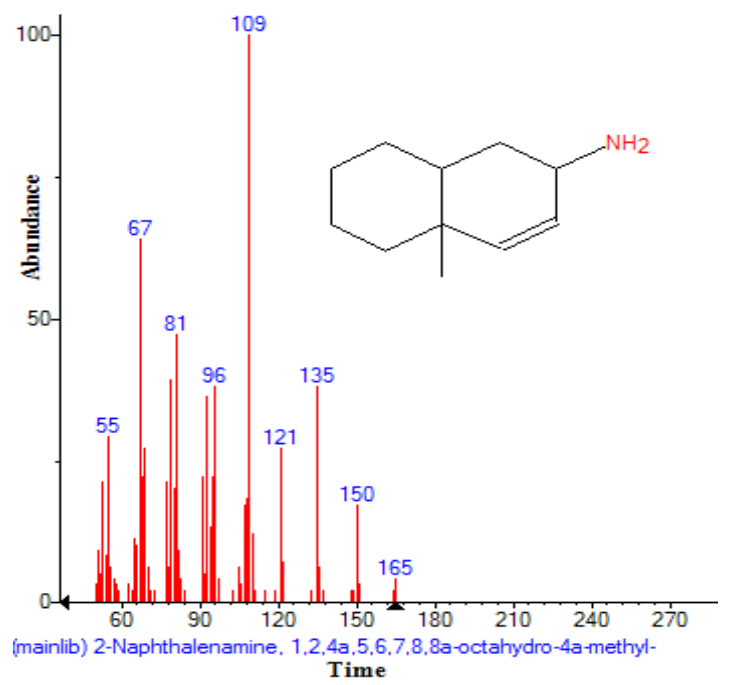

Fig. 3: Structure of 2-Naphthalenamine,

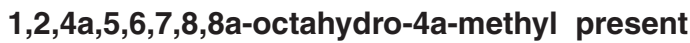
in Zingiber officinale with retention time $=4.987$ using GC-MS analysis

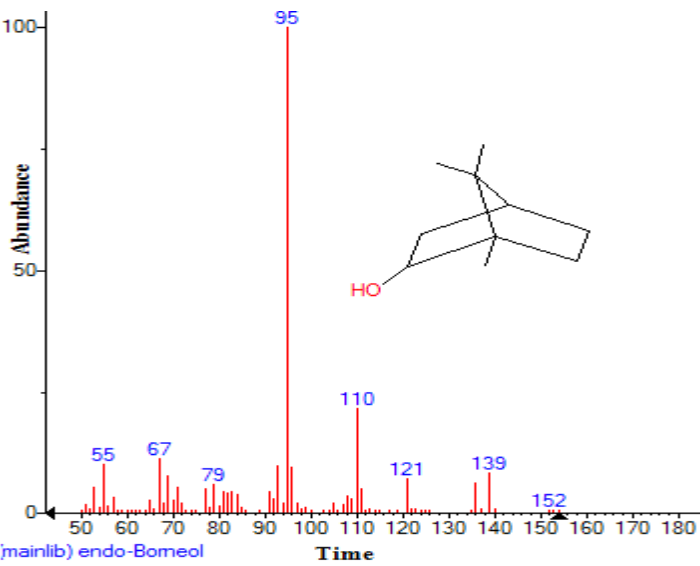

Fig. 5: Structure of Endo-Borneol present in Zingiber officinale with retention time $=\mathbf{5 , 9 8 2}$ using GC-MS analysis 
flow rate of the gas used and the electron gun were programmed initially. The temperature of the oven was maintained at $100^{\circ} \mathrm{C}$. Helium gas was used as a carrier as well as an eluent. The flow rate of helium was set to $1 \mathrm{ml}$ per minute. The electron gun of mass detector liberated electrons having energy

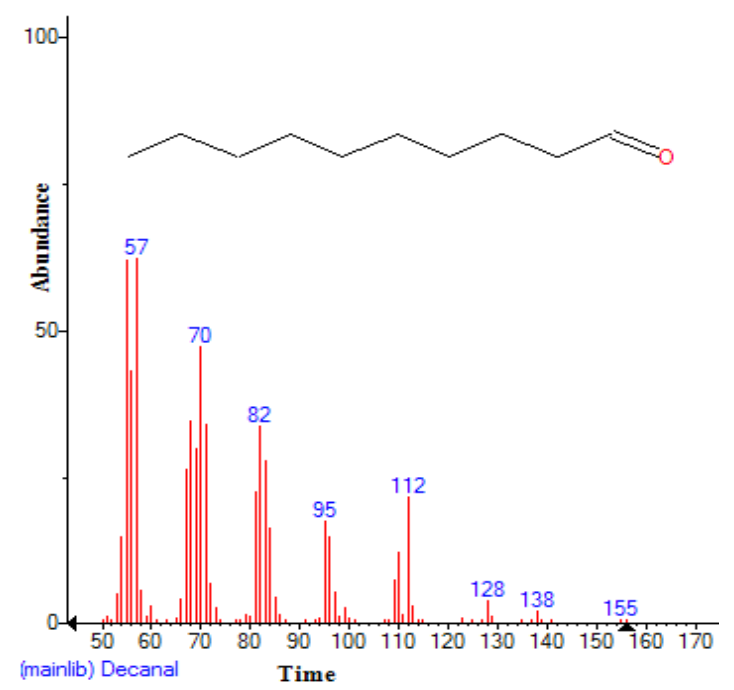

Fig. 6: Structure of Decanal present in Zingiber officinale with retention time $=6.417$ using GCMS analysis

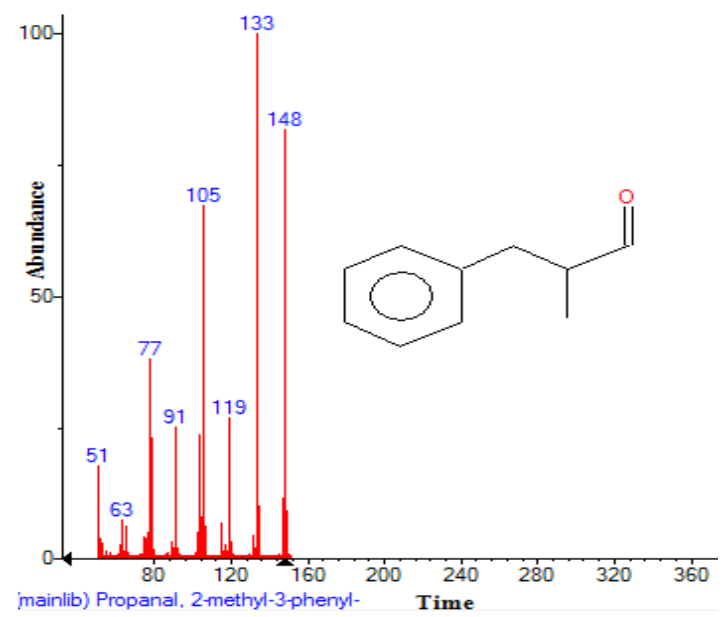

Fig. 8: Structure of Propanal,2-methyl-3-phenyl present in Zingiber officinale with retention time $=6.932$ using GC-MS analysis of about 70eV.The column employed here for the separation of components was Elite 1(100\% dimethyl poly siloxane). The identity of the components in the extracts was assigned by the comparison of their retention indices and mass spectra fragmentation patterns with those stored on the computer library

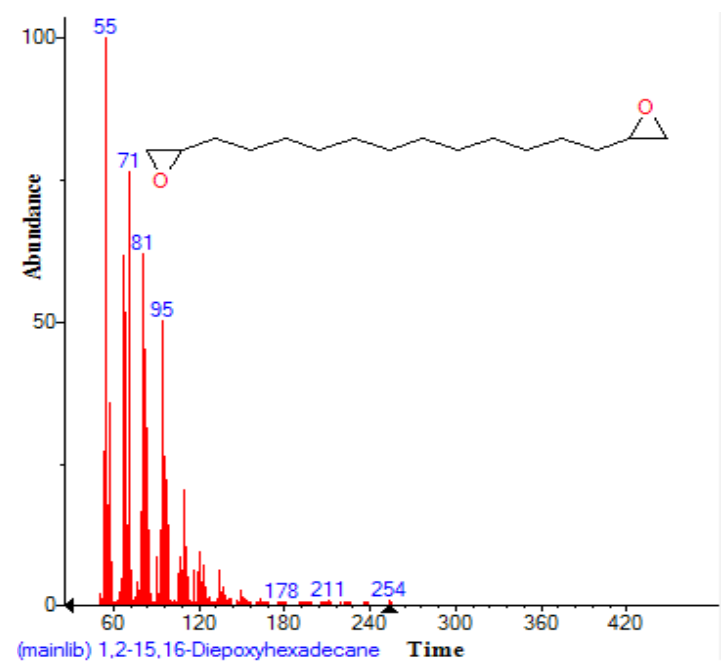

Fig. 7: Structure of 1,2-15,16-

Diepoxyhexadecane present in Zingiber officinale with retention time $=6.697$ using GCMS analysis

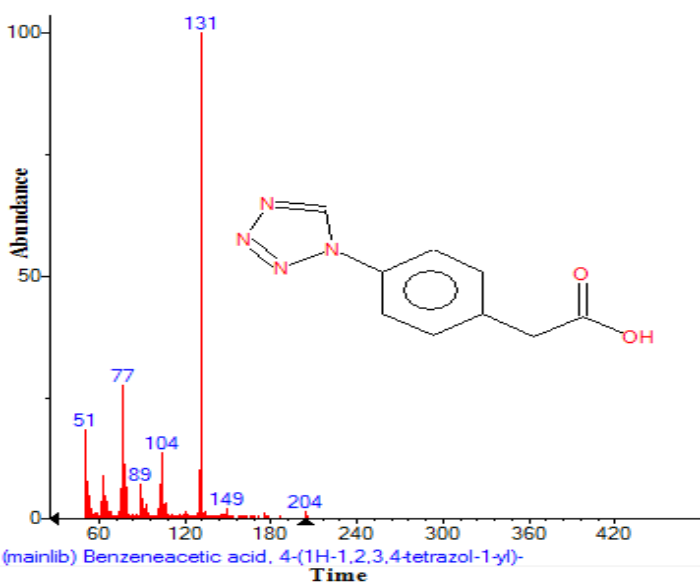

Fig. 9: Structure of Benzeneacetic acid ,4-(1H1,2,3,4-tetrazol-1-yl) present in Zingiber officinale with retention time $=7.338$ using GCMS analysis 
and also with published literatures. Compounds were identified by comparing their spectra to those of the Wiley and NIST/EPA/NIH mass spectral libraries ${ }^{22}$.

Determination of antibacterial activity of crude bioactive compounds of Zingiber officinale

The test pathogens (Klebsiella pneumoniae, Pseudomonas aeruginosa, Klebsiella pneumoniae,
E. coli, and Staphylococcus aureus) were swabbed in Muller-Hinton agar plates. 60il of plant extract was loaded on the bored wells. The wells were bored in $0.5 \mathrm{~cm}$ in diameter ${ }^{24}$. The plates were incubated at $37 \mathrm{C}^{\circ}$ for $24 \mathrm{hrs}$ and examined. After the incubation the diameter of inhibition zones around the discs was measured.

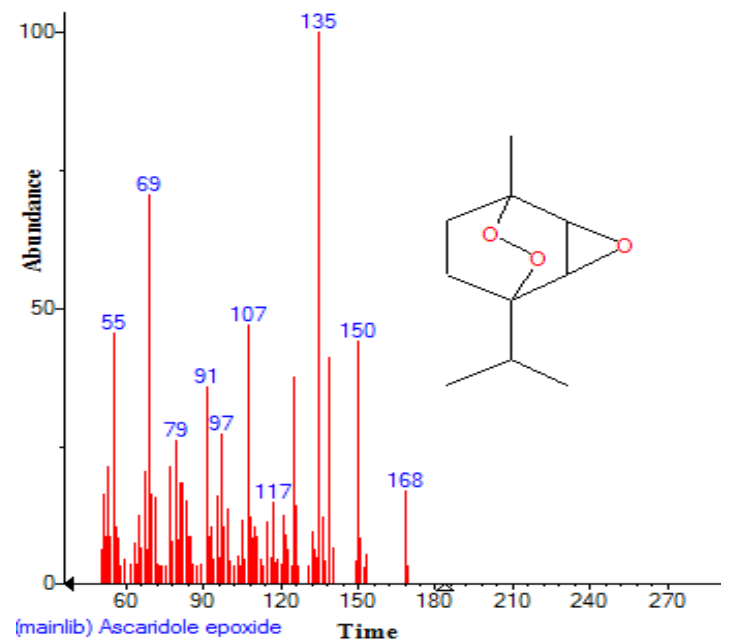

Fig. 10: Structure of Ascaridole epoxide present in Zingiber officinale with retention time $=7.750$ using GC-MS analysis

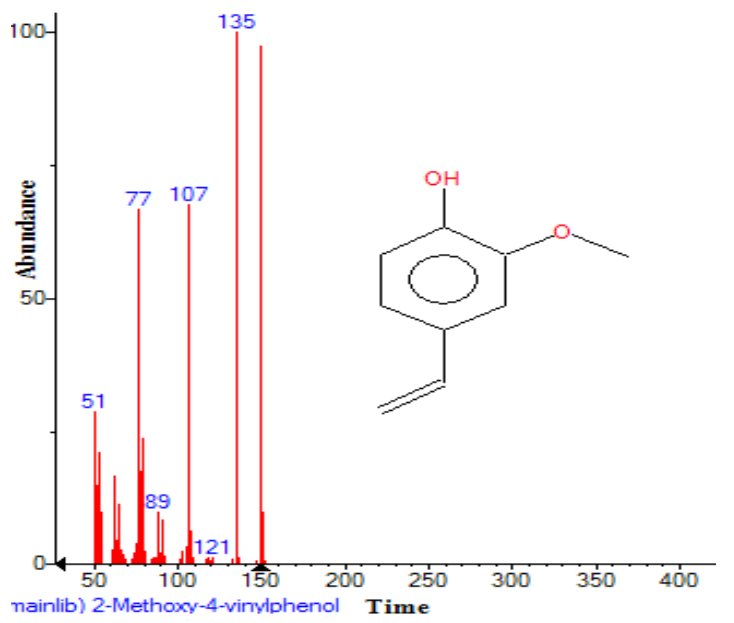

Fig. 11: Structure of 2-Methoxy-4-vinylphenol present in Zingiber officinale with retention time $=7.928$ using GC-MS analysis

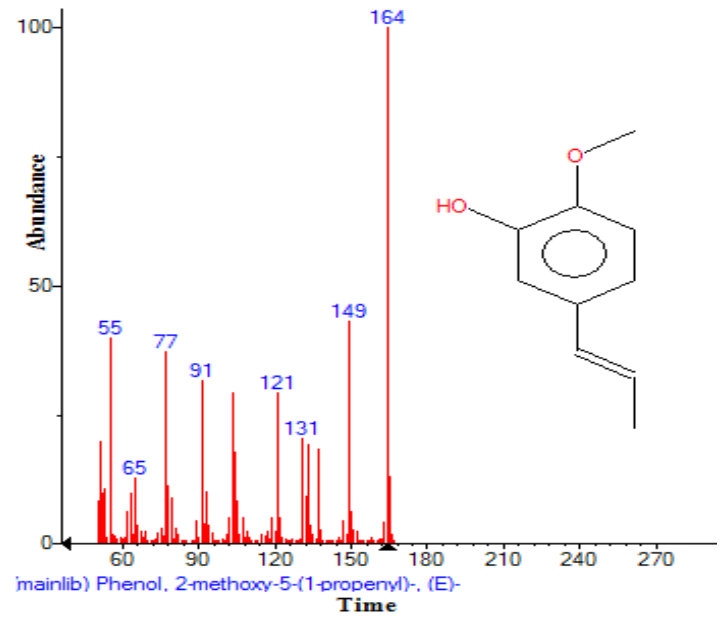

Fig. 13: Structure of Phenol,2-methoxy-5-(1propenyl)-,E present in Zingiber officinale with retention time $=8.414$ using GC-MS analysis using GC-MS analysis 


\section{RESULTS AND DISCUSSION}

Gas chromatography and mass spectroscopy analysis of compounds was carried out in methanolic roscoe extract of Zingiber officinale, shown in Table 1. The GC-MS chromatogram of the 48 peaks of the compounds detected was shown in Figure 1. Chromatogram GC-MS analysis of the methanol extract of Zingiber officinale showed the presence of forty eight major peaks and the

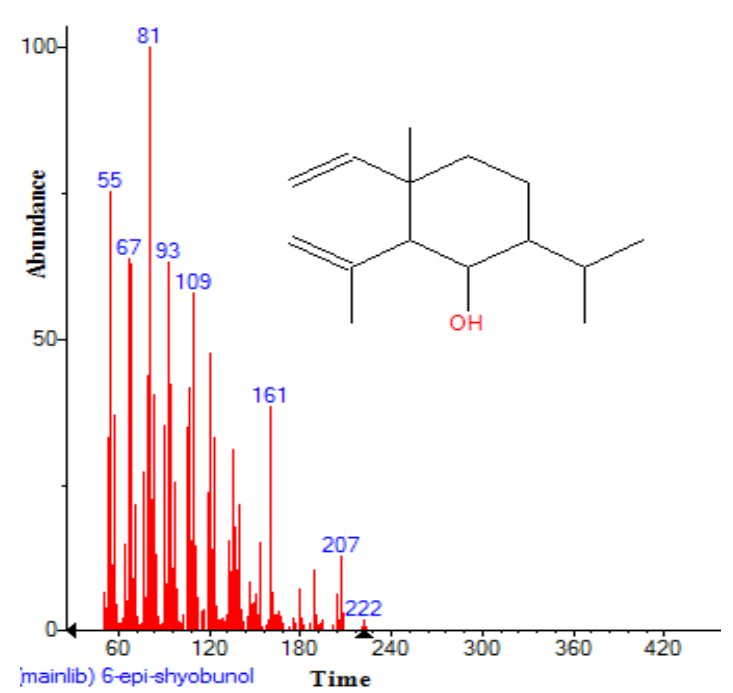

Fig. 14: Structure of 6-epi-shyobunol present in Zingiber officinale with retention time $=\mathbf{8 . 6 1 4}$ using GC-MS analysis

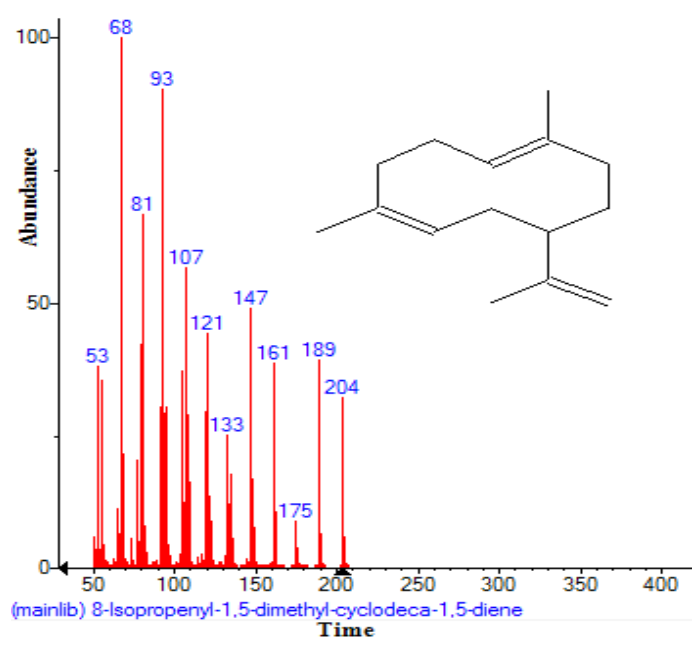

Fig. 16: Structure of 8-Isopropenyl-1,5dimethyl-cyclodeca-1,5-diene present in Zingiber officinale with retention time $=\mathbf{8 . 9 0 0}$ using GC-MS analysis

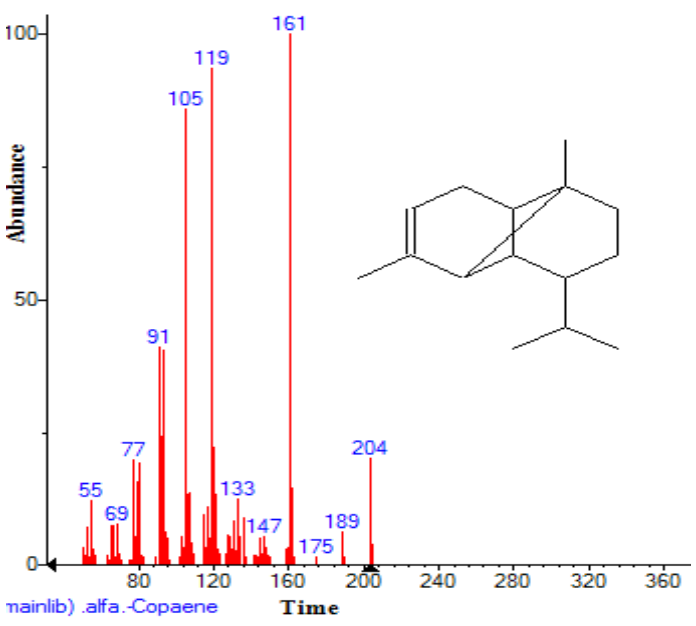

Fig. 15: Structure of Alfa.-Copaene present in Zingiber officinale with retention time $=8.717$ using GC-MS analysis

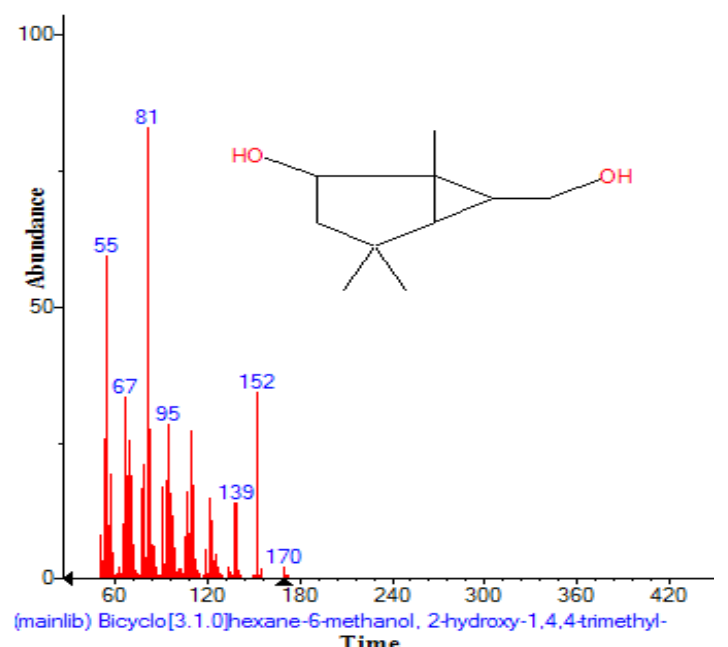

Fig. 17: Structure of Bicyclo[3.1.0]hexane-6methanol,2-hydroxy-1,4,4-trimethyl present in Zingiber officinale with retention time $=9.055$ using GC-MS analysis 
components corresponding to the peaks were determined as follows. The First set up peak were determined to be Octanal Figure 2. The second peak indicated to be, 2-Naphthalenamine,1,2,4 a, 5,6,7,8,8a-octahydro-4a-methyl, Figure 3. The next peaks considered to be 1-(Cyclopropyl-nitro- methyl)-cyclopentanol, Endo-Borneol, Decanal, 1,2-15,16-Diepoxyhexadecane, Propanal,2-methyl3-phenyl, Benzeneacetic acid ,4-(1H-1,2,3,4-tetrazol1-yl), Ascaridole epoxide, 2-Methoxy-4-vinylphenol, 6-epi-shyobunol, Phenol,2-methoxy-5-(1-propenyl),E, Alfa.-Copaene, 8-Isopropenyl-1,5-dimethyl-

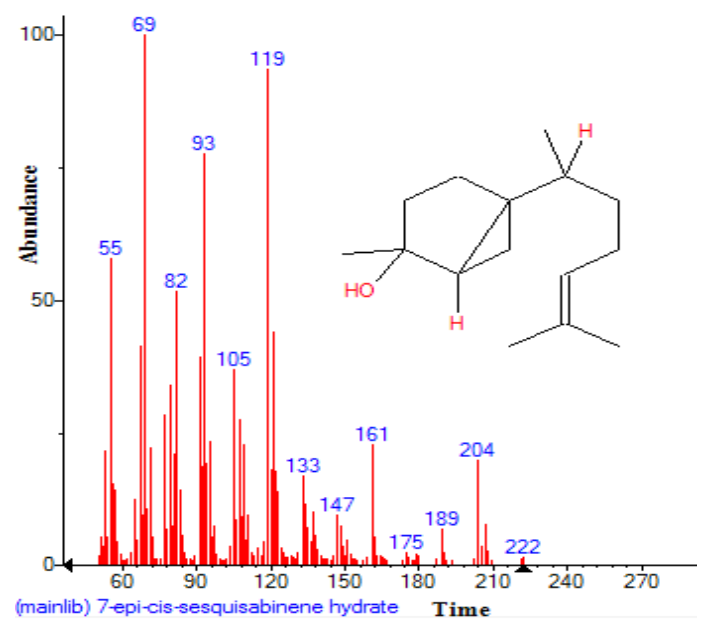

Fig. 18: Structure of 7-epi-cis-sesquisabinene hydrate present in Zingiber officinale with retention time $=9.335$ using GC-MS analysis

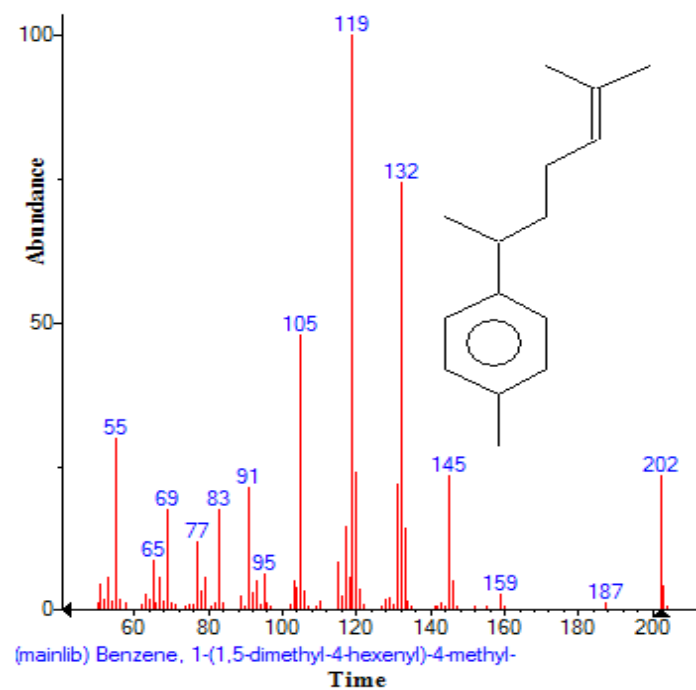

Fig. 20: Structure of Benzene,1-(1,5-dimethyl-4hexenyl)-4-methyl present in Zingiber officinale with retention time $=10.037$ using GC-MS analysis

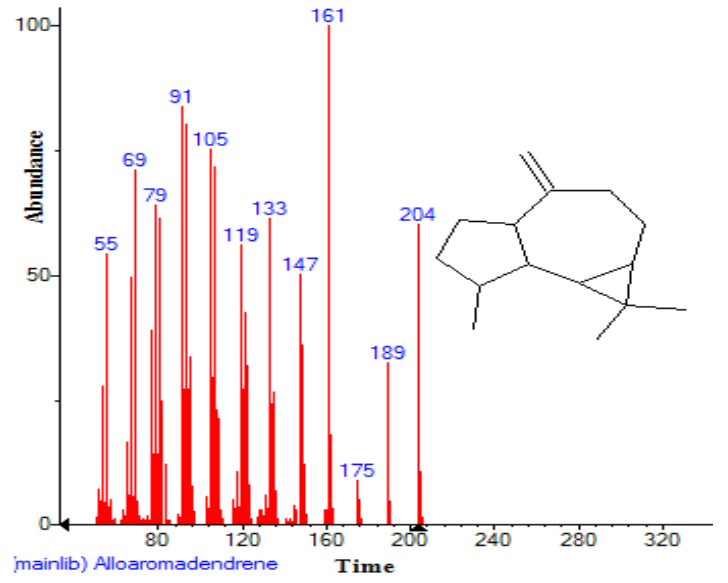

Fig. 19: Structure of Alloaromadendrene present in Zingiber officinale with retention time $=9.845$ using GC-MS analysis

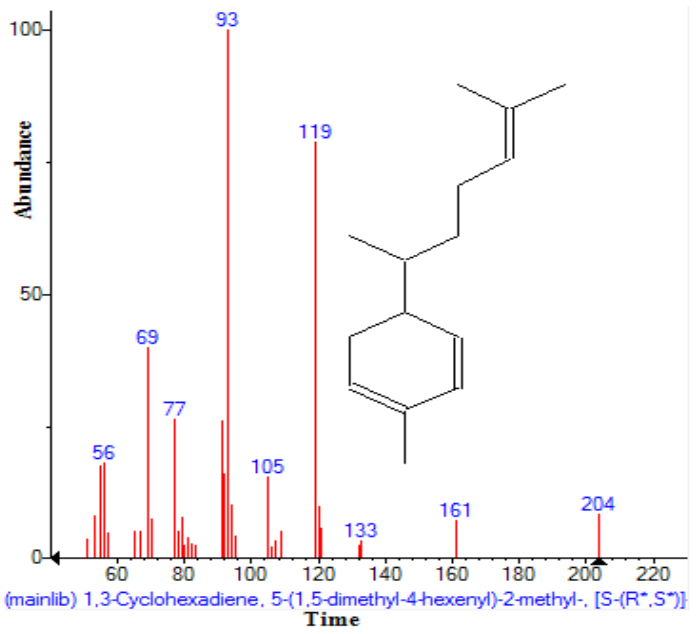

Fig. 21: Structure of 1,3-Cyclohexadiene ,5-(1,5-dimethyl-4-hexenyl)-2methyl-,[S-( $\left.\left(\mathrm{R}^{\star}, \mathrm{S}^{\star}\right)\right]$ present in Zingiber officinale with retention time $=10.228$ using GC-MS analysis 
cyclodeca-1,5-diene, Bicyclo[3.1.0]hexane-6methanol,2-hydroxy-1,4,4-trimethyl, 7-epi-cissesquisabinene hydrate, Alloaromadendrene, Benzene,1-(1,5-dimethyl-4-hexenyl)-4-methyl, 1,3-Cyclohexadiene ,5-(1,5-dimethyl-4-hexenyl)-

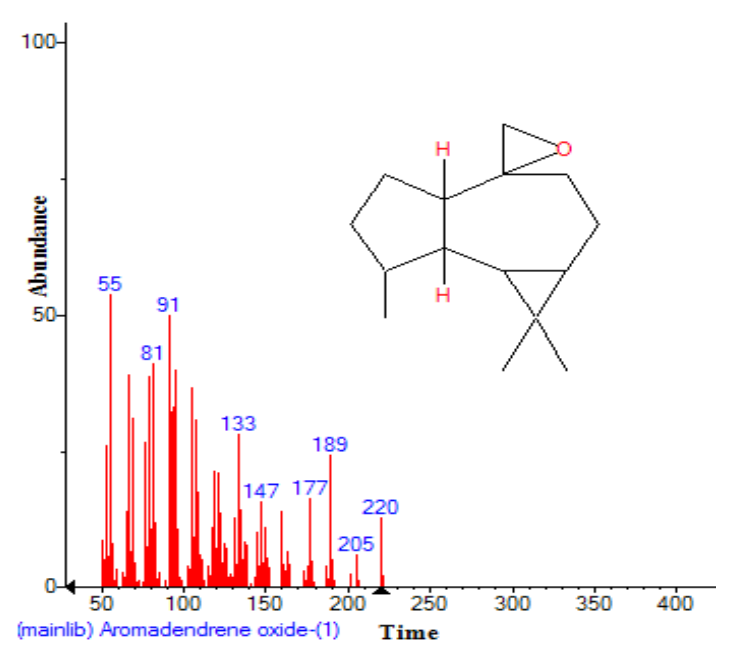

Fig. 22: Structure of Aromadendrene oxide present in Zingiber officinale with retention time $=10.869$ using GC-MS analysis

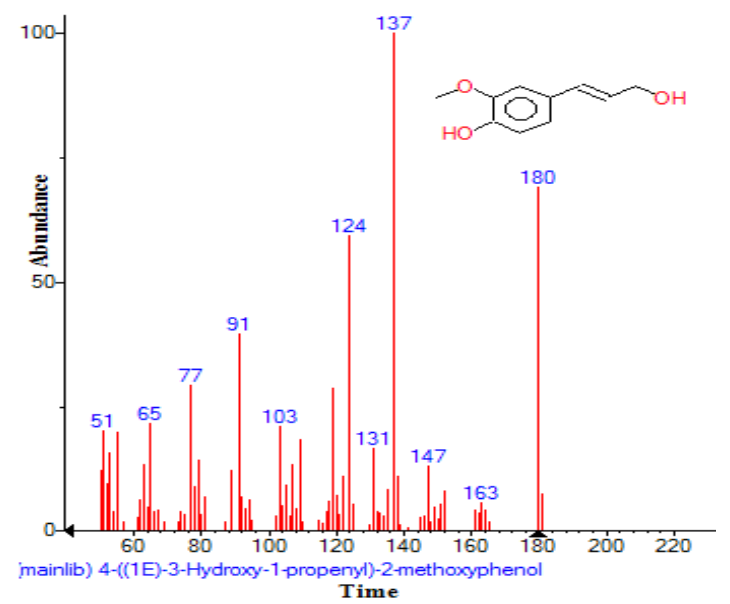

Fig. 24: Structure of 4-((1H)-3-Hydroxy-1propenyl)-2-methoxyphenol present in Zingiber officinale with retention time $=\mathbf{1 1 . 2 2 4}$ using GC-MS analysis 2methyl-, [S- $\left.\left(\mathrm{R}^{*}, \mathrm{~S}^{*}\right)\right]$, Aromadendrene oxide, 1,6,10-Dodecatrien-3-ol,3,7,11-trimethyl-,(E), 4-((1H)-3-Hydroxy-1-propenyl)-2-methoxyphenol, Butan-2-one,4-(3-hydroxy-2-methoxyphenyl), Longipinocarveol,trans, Cholestan-3-ol,2-methylene-

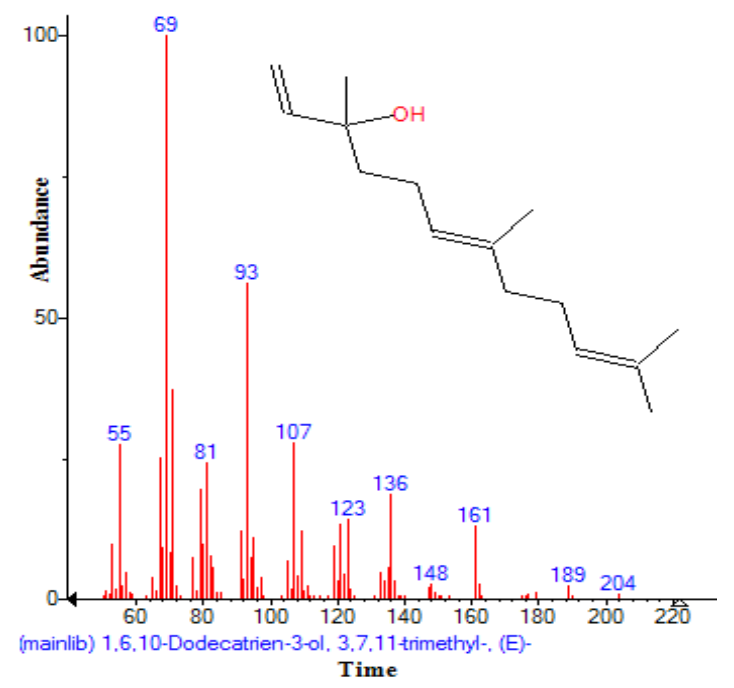

Fig. 23: Structure of 1,6,10-Dodecatrien-3ol,3,7,11-trimethyl-,(E) present in Zingiber officinale with retention time $=\mathbf{1 0 . 9 7 2}$ using GC-MS analysis

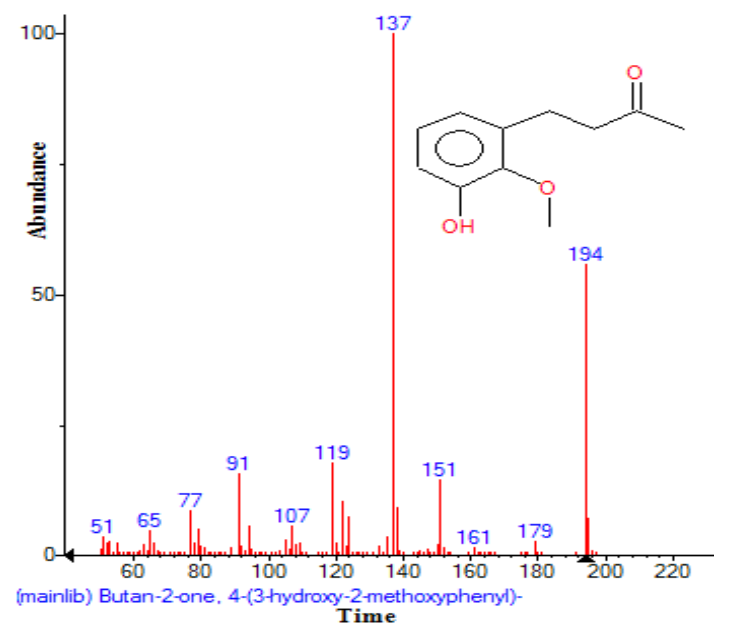

Fig. 25: Structure of Butan-2-one,4-(3hydroxy-2-methoxyphenyl) present in Zingiber officinale with retention time $=\mathbf{1 2 . 2 4 8}$ using GC-MS analysis 
,(3ß,5á)-, Bicyclo[4.4.0]dec-2-ene-4-ol,2-methyl-9(prop-1-en-3-ol-2-yl)-, Corymbolone, Estra-1,3,5(10)trien-17ß-ol, 1-Heptatriacotanol, Fenretinide, Folic acid, Spiro[4.5]decan-7-one,1,8-dimethyl-8,9-epoxy- 4-isopropyl-, 7H-6,9a-Methano-4H-cyclopenta[9,10] cyclopropa[5,6]cyclodeca[1, Gingerol, 1b,4a-Epoxy$2 \mathrm{H}$-cyclopenta[3,4]cyclopropa [8,9]cycloundec[1,2-b] o, Cyclopropa[5,6]-A-nor-5á-androstane-3,7-

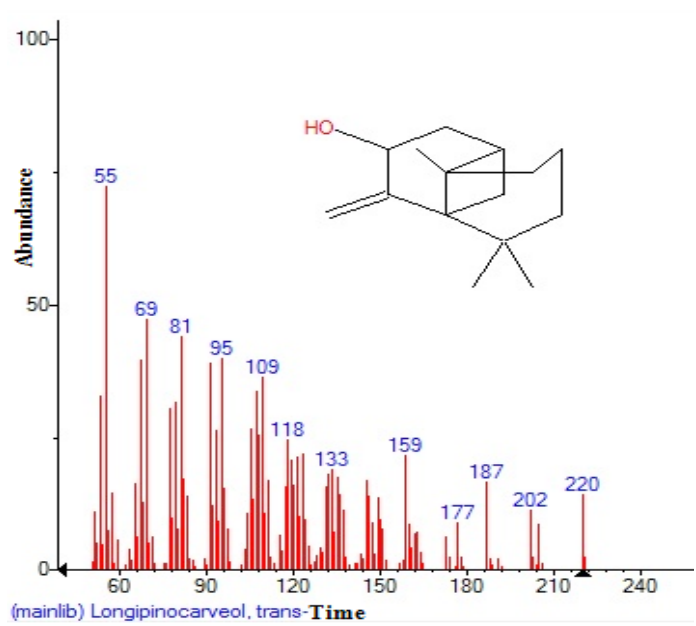

Fig. 26: Structure of Longipinocarveol,trans present in Zingiber officinale with retention time $=12.631$ using GC-MS analysis

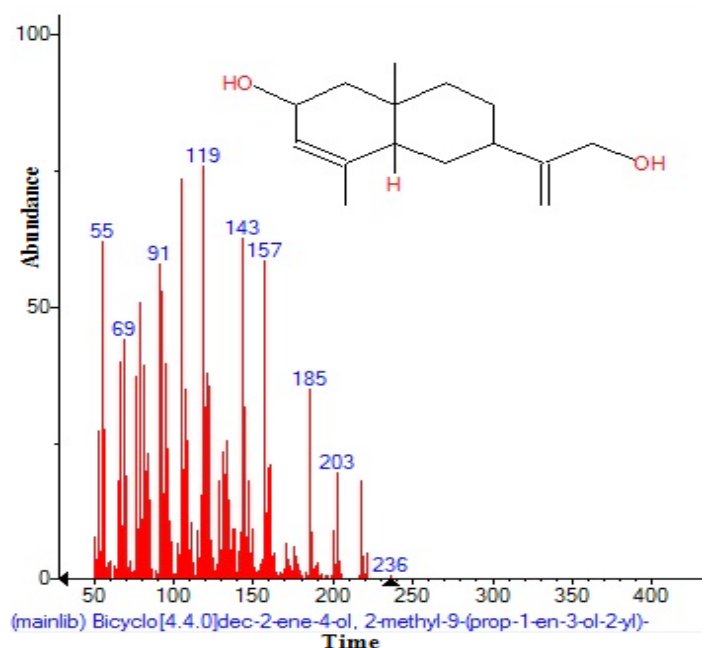

Fig. 28: Structure of Bicyclo[4.4.0]dec-2-ene4-ol,2-methyl-9-(prop-1-en-3-ol-2-yl) present in Zingiber officinale with retention time $=13.427$ using GC-MS analysis

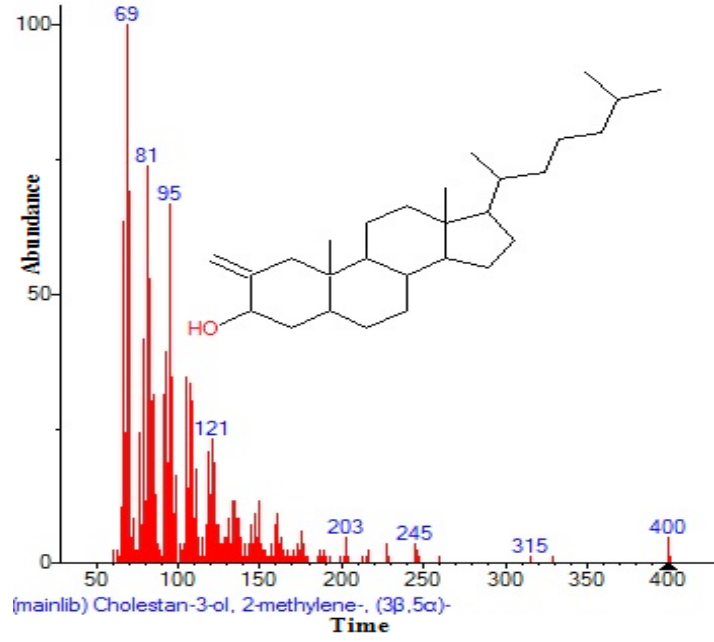

Fig. 27: Structure of Cholestan-3-ol,2methylene-, $(3 \beta, 5 \alpha)$ present in Zingiber officinale with retention time $=12.837$ using GCMS analysis

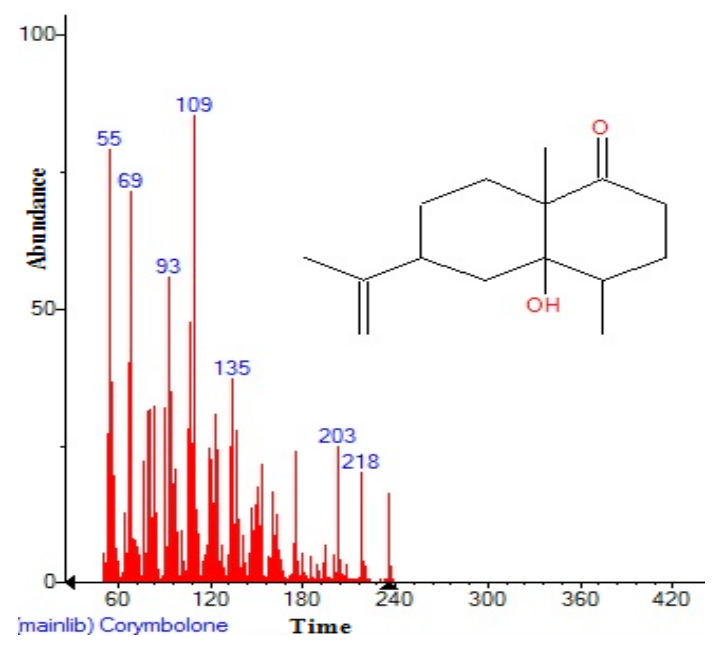

Fig. 29: Structure of Corymbolone present in Zingiber officinale with retention time $=\mathbf{1 4 . 2 6 8}$ using GC-MS analysis 
dione, 3',6ß-dihydro-17ß-h, Olean-12-ene3,15,16,21,22,28-hexol,(3ß,15á,16á,21ß,22á)-, Benz[e]azulen-3(3aH)-one,4,6a,7,8,9,10,10a,10boctahydro-3a,8,1, Naphthalene, decahydro1-pentadecyl-, 13-Docosenamide,(Z)-, 9,10-

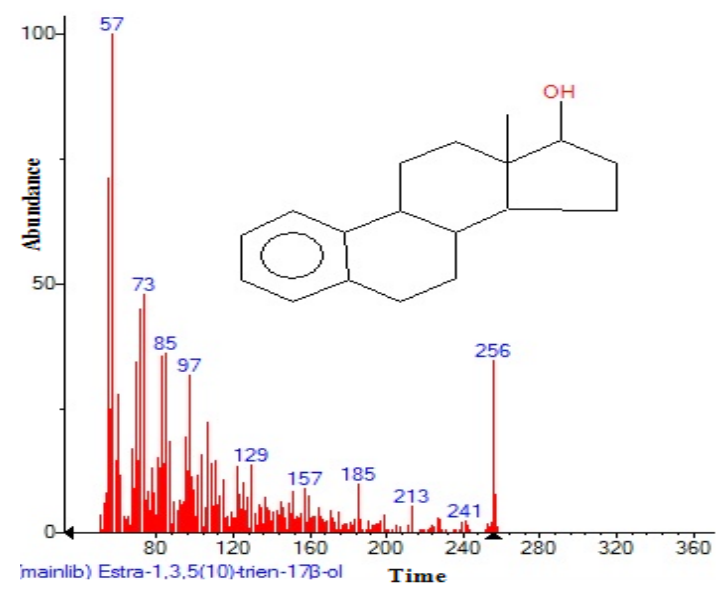

Fig. 30: Structure of Estra-1,3,5(10)-trien-17ßol present in Zingiber officinale with retention time=15.240 using GC-MS analysis
Secocholesta-5,7,10(19)-triene-3,24,25-triol, (3ß,5Z,7E)-, n-(2,4-Dinitrophenyl)-N'-13-(2,6,6trimethyl-cyclohex-1-enyl)propylider, n-(2,4Dinitrophenyl)-N'-13-(2,6,6-trimethyl-cyclohex-1enyl)propylider, Ingol 12-acetate, 2,2,4-Trimethyl-3-

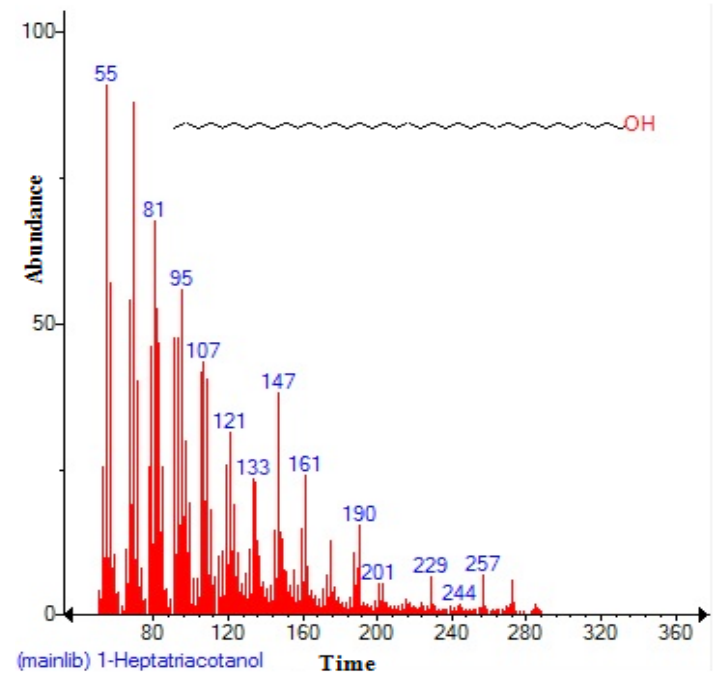

Fig. 31: Structure of 1-Heptatriacotanol present in Zingiber officinale with retention time= 15.166 using GC-MS analysis

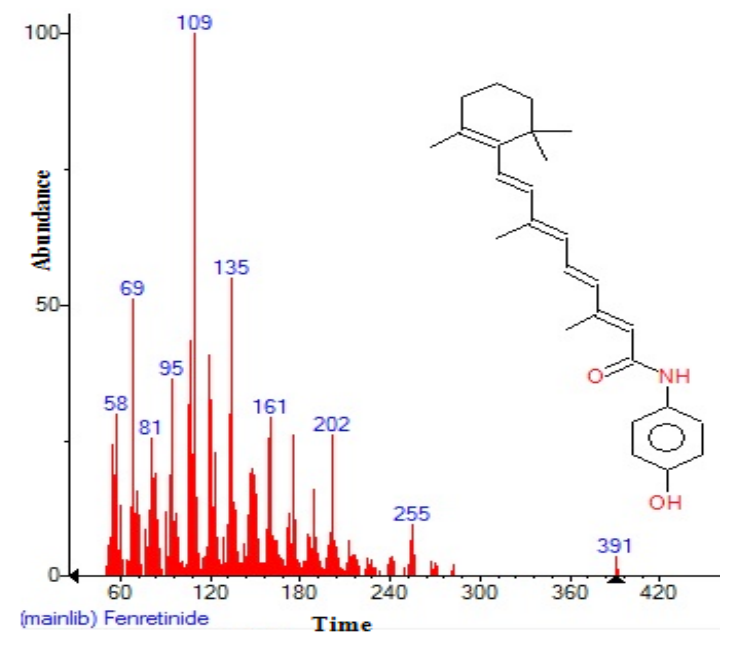

Fig. 32: Structure of Fenretinide present in Zingiber officinale with retention time $=16.059$ using GC-MS analysis

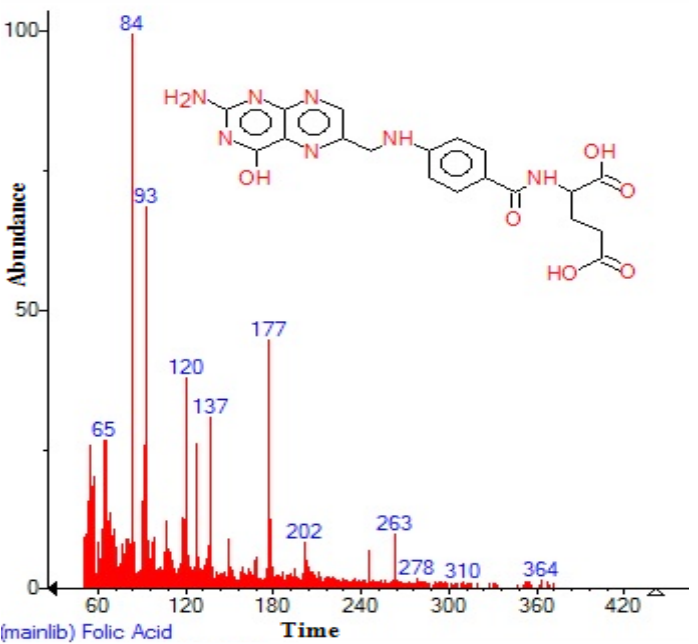

Fig. 33: Structure of Folic acid present in Zingiber officinale with retention time $=15.675$ using GC-MS analysis 
(3,8,12,16-tetramethyl-heptadeca-3,7,11,15-tetrae, Piperine, 2-Methylcortisol, 9-Desoxo-9-x-acetoxy3,8,12,-tri-O-acetylingol and Propanoic acid ,2-(3acetoxy-4,4,14-trimethylandrost-8-en-17-yl. (Figure 4-50). In this study five clinical pathogens selected for antibacterial activity namely, (staphylococcus aeureus, klebsiella pneumoniae, pseudomonas aeroginosa, E.coli. and Proteus mirabilis. Maximum zone formation against Klebsiella pneumoniae, Table 2.

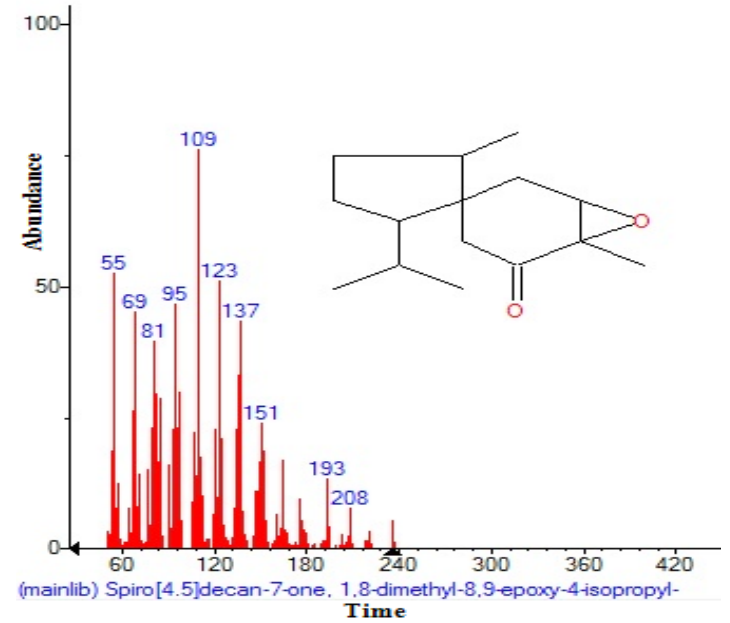

Fig. 34: Structure of Spiro[4.5]decan-7-one,1,8dimethyl-8,9-epoxy-4-isopropyl present in Zingiber officinale with retention time $=\mathbf{1 5 . 0 3 4}$ using GC-MS analysis

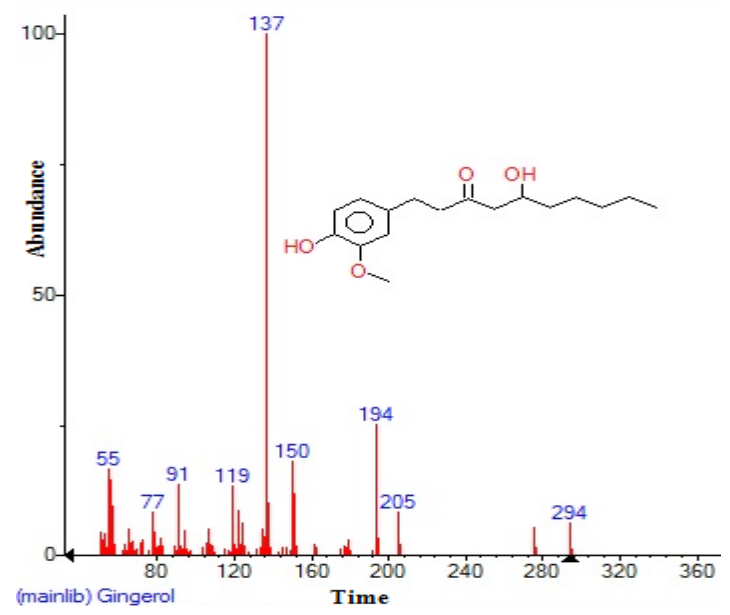

Fig. 36: Structure of Gingerol present in Zingiber officinale with retention time $=18.799$ using GC-MS analysis

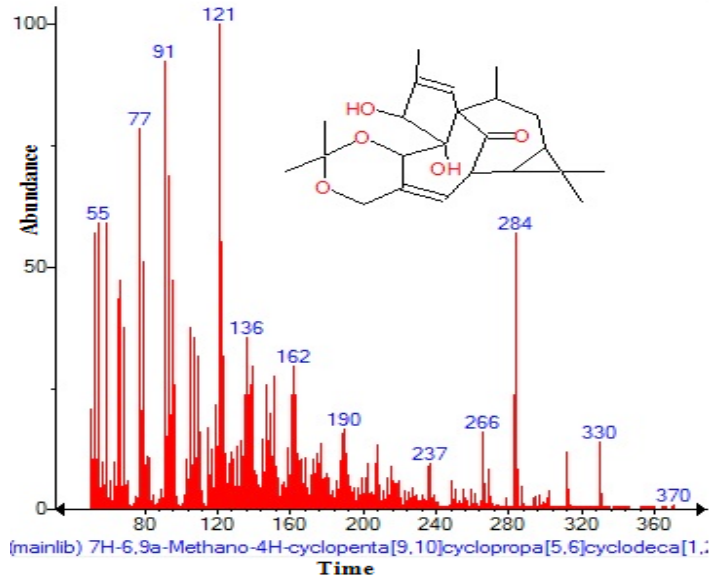

Fig. 35: Structure of $7 \mathrm{H}-6,9 \mathrm{a}-M e t h a n o-4 \mathrm{H}-$ cyclopenta[9,10]cyclopropa[5,6]cyclodeca[1, present in Zingiber officinale with retention time $=17.495$ using GC-MS analysis

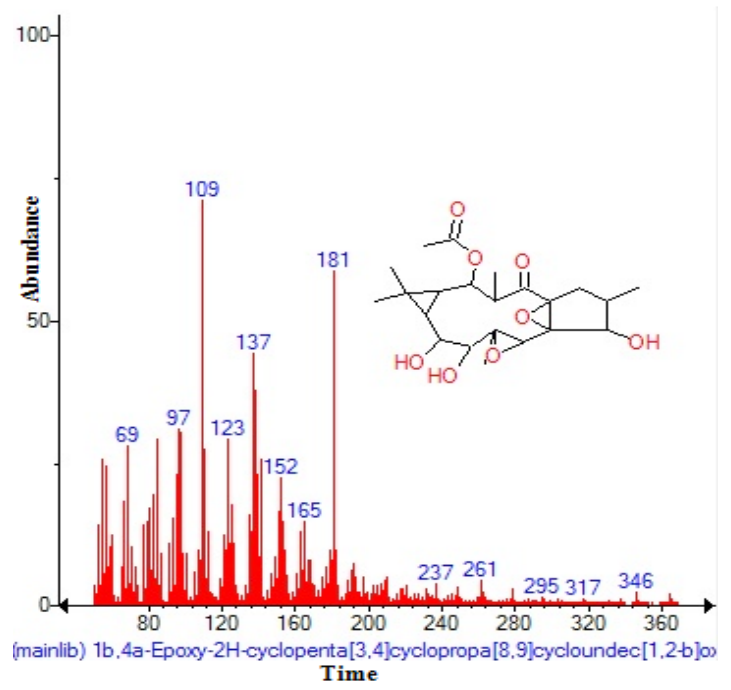

Fig. 37: Structure of 1b,4a-Epoxy$2 \mathrm{H}$-cyclopenta[3,4]cyclopropa[8,9] cycloundec[1,2-b]o present in Zingiber officinale with retention time $=18.897$ using GCMS analysis 


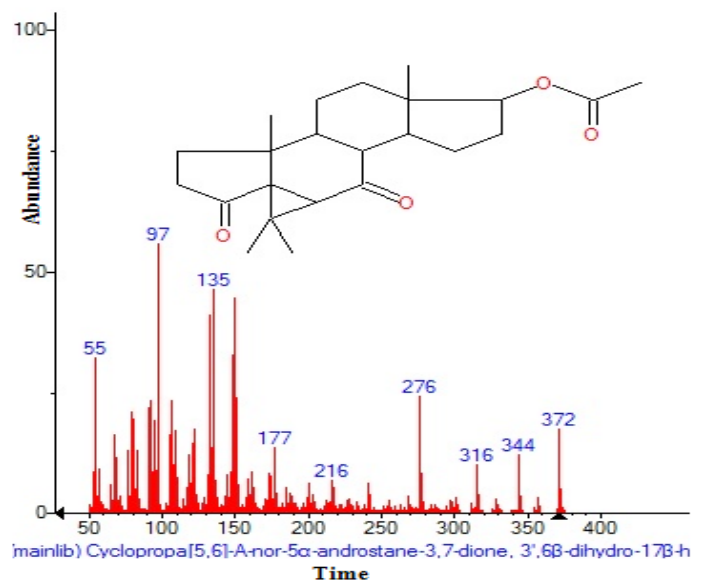

Fig. 38: Structure of Cyclopropa[5,6]-A-nor5á-androstane-3,7-dione,3',6ß-dihydro-17ß-h present in Zingiber officinale with retention time= 19.795 using GC-MS analysis

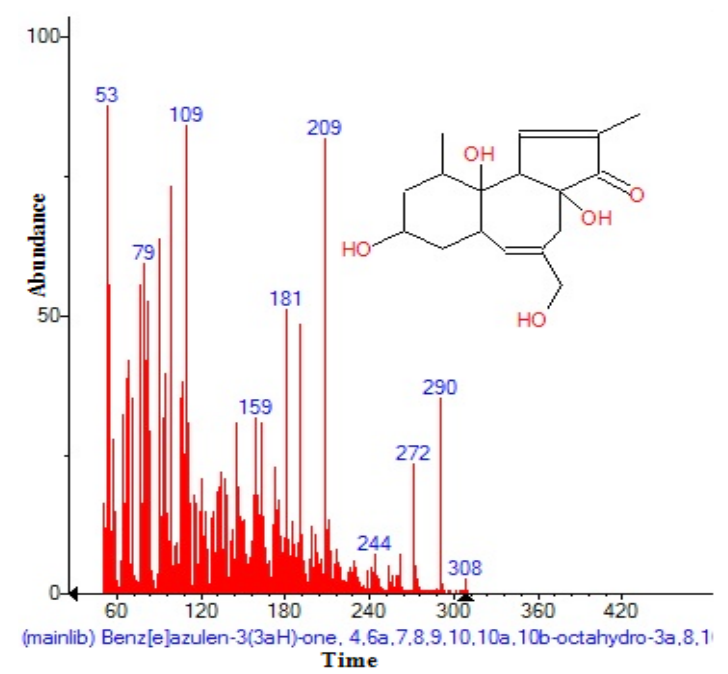

Fig. 40: Structure of Benz[e]azulen-3(3aH)one,4,6a,7,8,9,10,10a,10b-octahydro-3a,8,1 present in Zingiber officinale with retention time $=20.768$ using GC-MS analysis

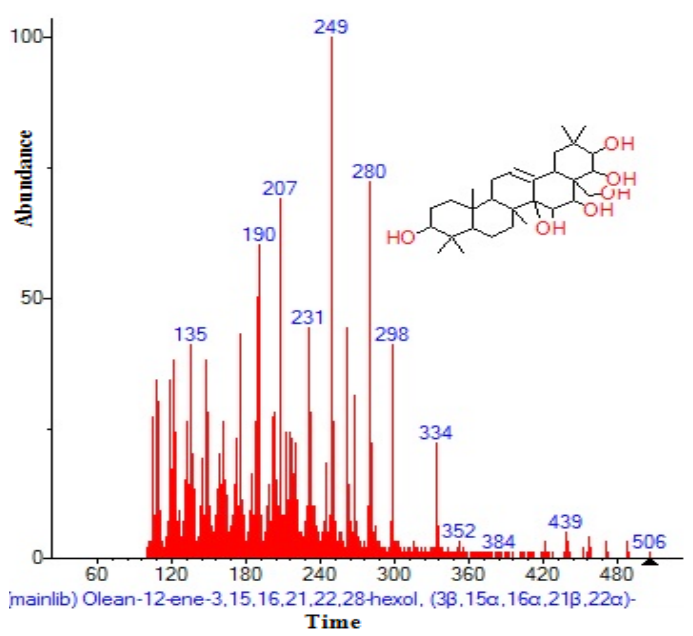

Fig. 39: Structure of Olean-12-ene3,15,16,21,22,28-hexol,(3ß,15á,16á,21ß,22á) present in Zingiber officinale with retention time $=\mathbf{2 0 . 5 3 3}$ using GC-MS analysis

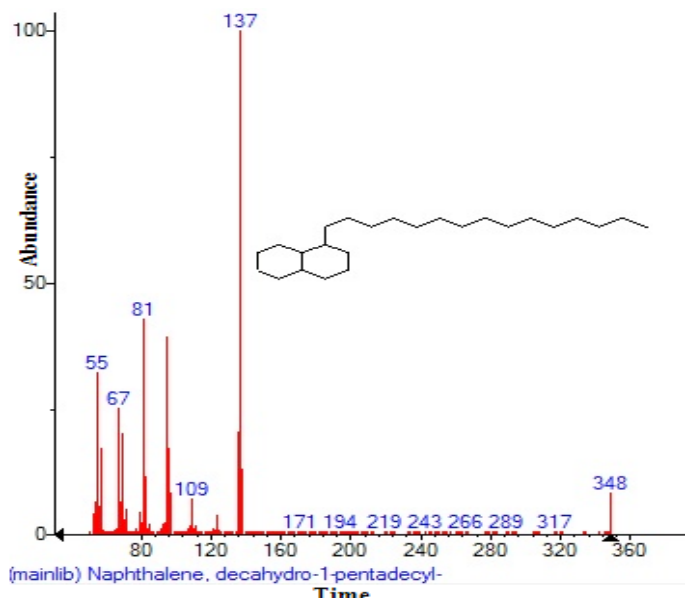

Fig. 41: Structure of Naphthalene,decahydro-1pentadecyl present in Zingiber officinale with retention time $=22.095$ using GC-MS analysis 


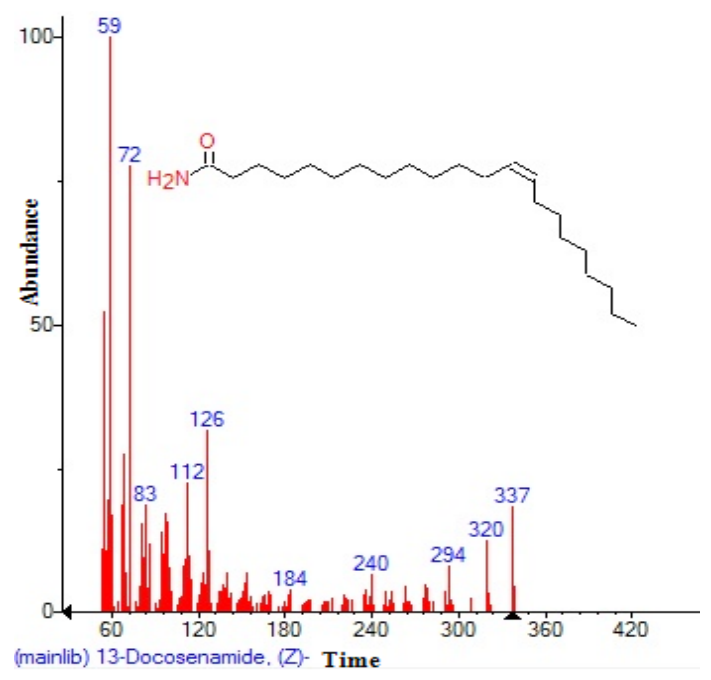

Fig. 42: Structure of 13-Docosenamide,(Z) present in Zingiber officinale with retention time $=22.175$ using GC-MS analysis

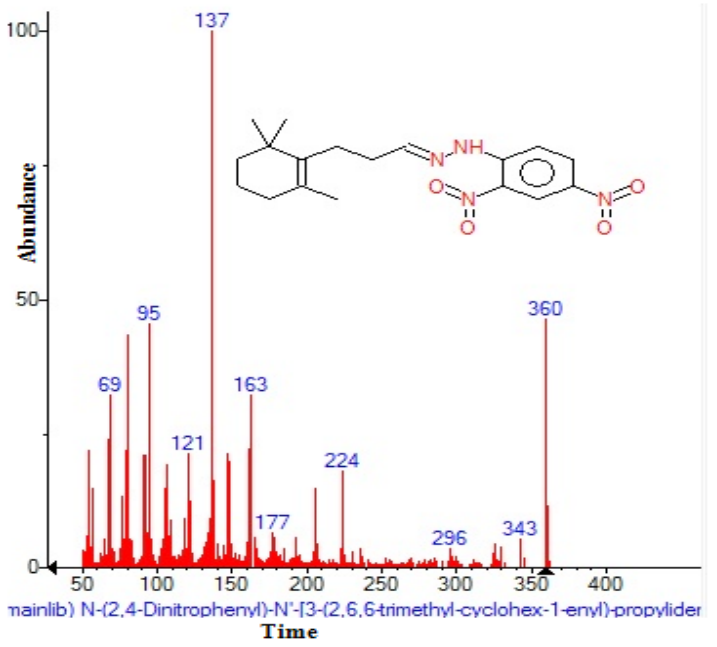

Fig. 44: Structure of $n-(2,4-D i n i t r o p h e n y l)-N^{2}-$ 13-(2,6,6-trimethyl-cyclohex-1-enyl)propylider present in Zingiber officinale with retention time= 22.862 using GC-MS analysis

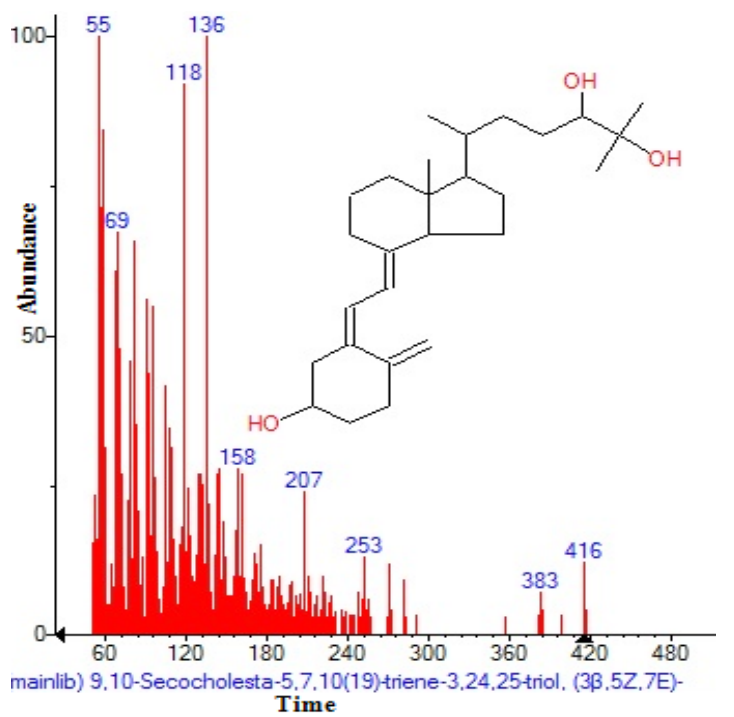

Fig. 43: Structure of 9,10-Secocholesta5,7,10(19)-triene-3,24,25-triol, (3ß,5Z,7E) present in Zingiber officinale with retention time $=22.811$ using GC-MS analysis

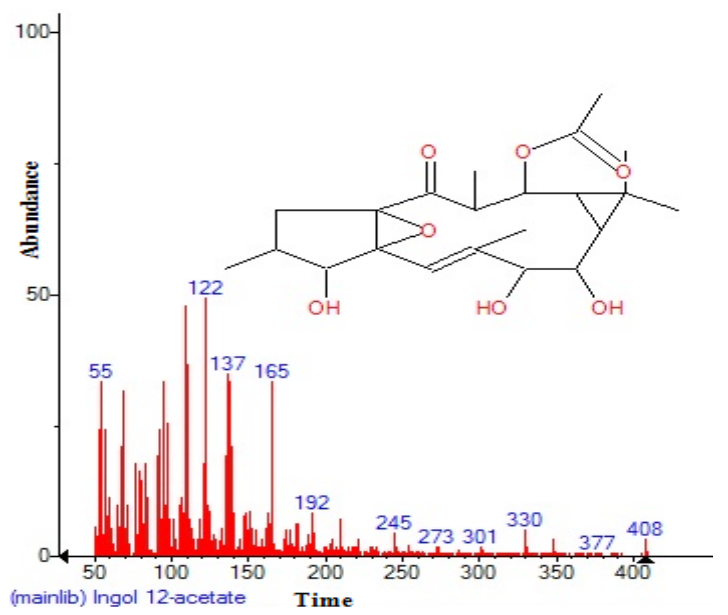

Fig. 45: Structure of Ingol 12-acetate present in Zingiber officinale with retention time $=\mathbf{2 2 . 9 1 4}$ using GC-MS analysis 


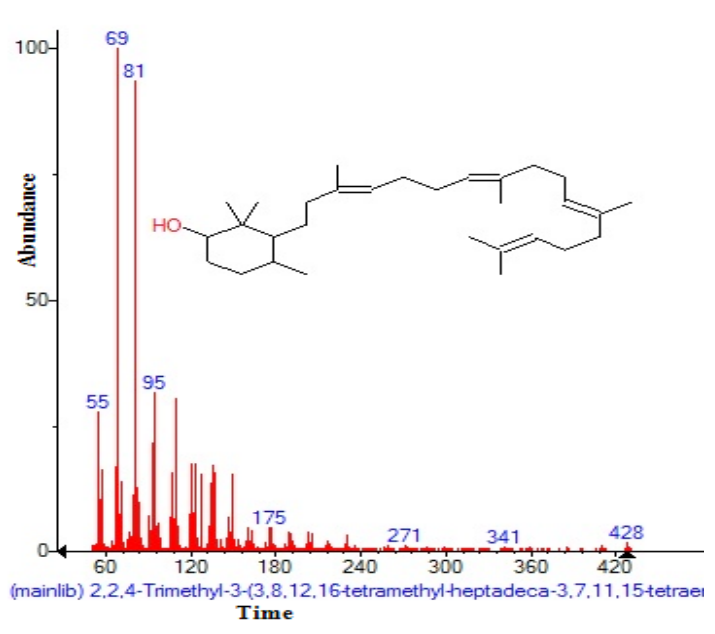

Fig. 46: Structure of 2,2,4-Trimethyl-3(3,8,12,16-tetramethyl-heptadeca-3,7,11,15tetrae present in Zingiber officinale with retention time $=\mathbf{2 3 . 5 5 4}$ using GC-MS analysis

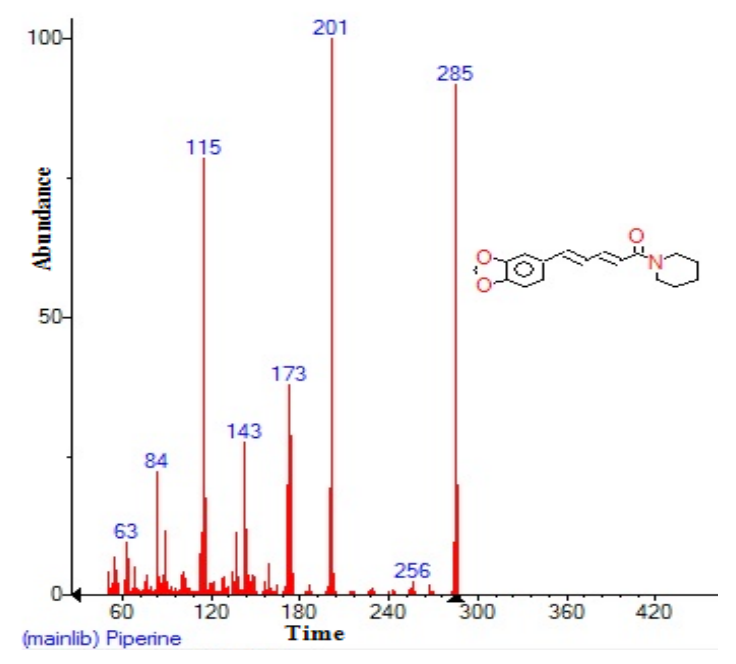

Fig. 47: Structure of Piperine present in Zingiber officinale with retention time $=23.629$ using GC-MS analysis

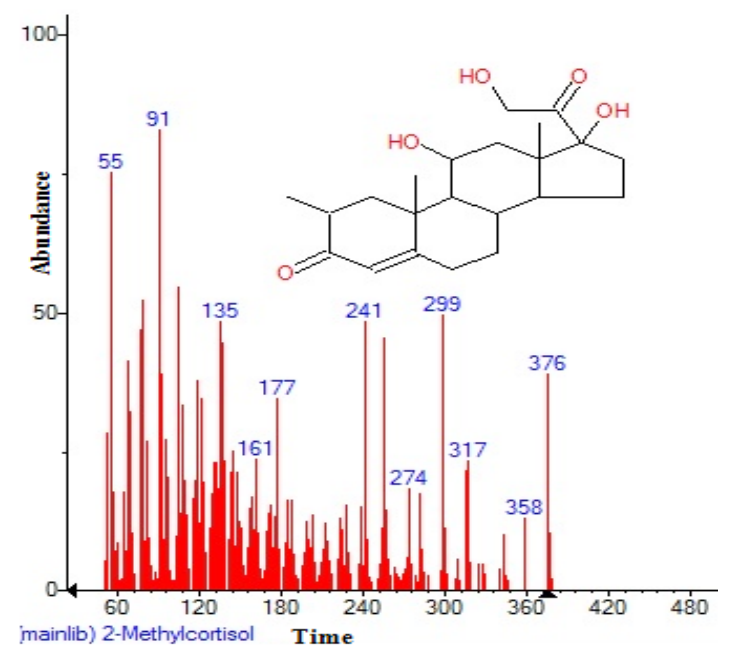

Fig. 48: Structure of 2-Methylcortisol present in Zingiber officinale with retention time $=24.195$ using GC-MS analysis

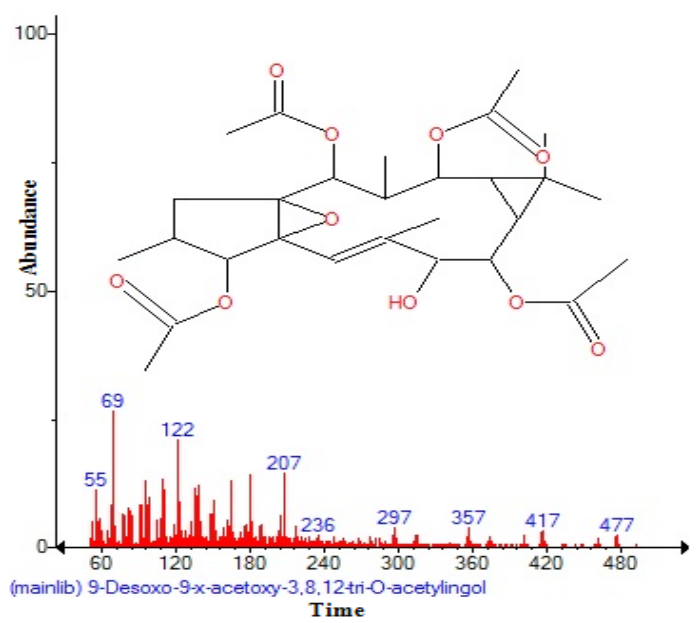

Fig. 49: Structure of 9-Desoxo-9-x-acetoxy3,8,12,-tri-O-acetylingol present in Zingiber officinale with retention time $=\mathbf{2 5}$.242 using GC-MS analysis 


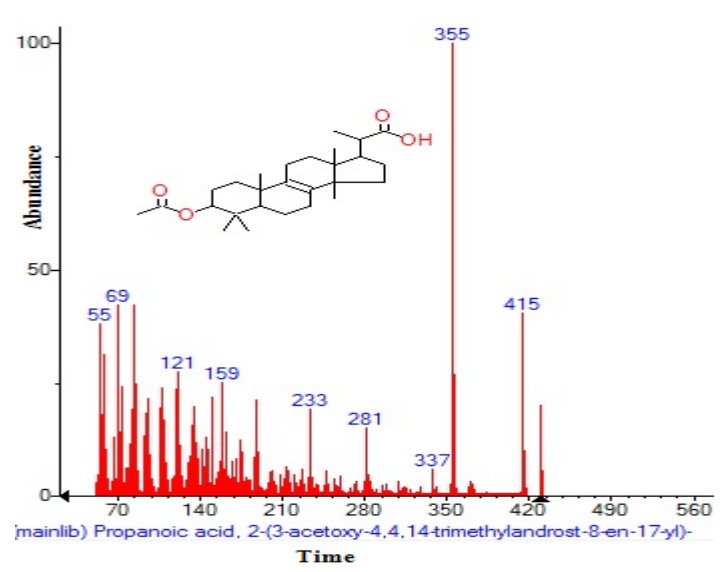

Fig. 50: Structure of Propanoic acid ,2-(3acetoxy-4,4,14-trimethylandrost-8-en-17-yl present in Zingiber officinale with retention time $=25.986$ using GC-MS analysis

\section{CONCLUSION}

From the results obtained in this study, it could be concluded that Zingiber officinale possesses remarkable antimicrobial activity, which is mainly due to naphthalenamine, decanal, and alfa.-copaene. According to these findings, it could be said that the methanolic extract act as antibacterial agents.

\section{ACKNOWLEDGEMENTS}

Special thanks to Prof. Abdul-Kareem, Babylon University, Faculty of science for women, for his special care.

\section{REFERENCES}

1. Ross, I.A. Medicinal Plants of the World. Humana Press, Totowa, New Jersey: 507560.

2. Chioma, A.A.; Onyechi, O.; Lawrence, U.S.; Meshach, M.N. African Journal of Biochemistry Research. 2009, 3(12), 379384.

3. Ahmed, R.S.; Seth, V.; Banergee, B.D. Indian J Exp Biol. 2000, 38(6), 604-6.

4. Ojewole, J.A. Phyother. Res. 2006, 20, 764772.

5. Nurtijahja, T.E.; Ammit, A.J., Roufoglis, B.D., Tran, V.H., Duke, C.C. Thromb. Res. 2003, 111, 259-265.

6. Chaieb, N., Gonzales, J.L.; Lopez-Mesas, M.; Bouslama, M.; Valiente, M. Food Research International. 2011, 44(4), 970-977.

7. Xu, B.J.; Yuan, S.H.; Chang, S.K.C. Journal of Food Science. 2007, 72(2), 167-177.

8. Ficker, C.E.; Arnason, J.T.; Vindas, P.S.; Alvarez, L.P.; Akpagana, K.; Gbeassor, M.; DeSouza, C.; Smith, M.L. Mycoses. 2003, 46: 29-37.

9. Al-Marzoqi, A.H.; Hameed, I.H.; Idan, S.A. African Journal of Biotechnology.2015, 14(40), 2812-2830.

10. Khushtar, M.; Kumar, V.; Javed, K., Uma, B. (2009). Indian J Pharm Sci. 1(5): 554-558.

11. Altameme, H.J.; Hadi, M.Y.; Hameed, I.H.
Journal of Pharmacognosy and Phytotherapy. 2015a, 7(10), 238-252.

12. Habib, S.H.; Makpol, S.; Hamid, N.A.; Das, S.; Ngah, W.Z.; Yusof, Y.A. Clinics. 2008, 63: 807-813.

13. Altameme, H.J.; Hameed, I.H.; Idan, S.A.; Hadi, M.Y. Journal of Pharmacognosy and Phytotherapy. 2015b, 7(9), 221-237.

14. Hamza, L.F.; Kamal, S.A.; Hameed, I.H. Journal of Pharmacognosy and Phytotherapy. 2015, 7(9), 194-220.

15. Altameme, H.J.; Hameed, I.H.; Kareem, M.A. African Journal of Biotechnology. 2015c, 14(19), 1668-1674.

16. Jasim, H.; Hussein, A.O.; Hameed, I.H.; Kareem, M.A. Journal of Pharmacognosy and Phytotherapy. 2015, 7(4): 56-72.

17. Mohammed, A.; Imad, H. Research Journal of Biotechnology. 2013, 8(10), 92-105.

18. Hameed, I.H.; Abdulzahra, A.I.; Jebor, M.A.; Kqueen, C.Y.; Ommer, A.J. Mitochondrial DNA. 2015a , 26(4), 544-9.

19. Hameed, I.H.; Hamza L.F.; Kamal S.A. Journal of Pharmacognosy and Phytotherapy. 2015b, 7(8), 132-163.

20. Muhanned, A.K.; Ameer, I.A.; Imad, H.H.; Mohammed, A.J. Mitochondrial DNA. 2015, 1-5.

21. Hameed, I.H.; Hussein, H.J.; Kareem, M.A.; 
Hamad, N.S. Journal of Pharmacognosy and 23. Idan, S.A.; Al-Marzoqi, A.H.; Hameed, I.H. Phytotherapy. 2015c, 7(7), 107-125.

22. Hameed, I.H.; Jebor, M.A.; Ommer, A.J.; Journal of Pharmacognosy and Phytotherapy. Abdulzahra, A.I.; Yoke, C. Mitochondrial DNA. 2014, 4:1-4. 2015, 14(46), 3131-3158.

24. Hameed, I.H.; Ibraheam, I.A.; Kadhim, H.J. Journal of Pharmacognosy and Phytotherapy. 2015d, 7(6), 90-106. 